\title{
Iron Isotope Fractionation in Subterranean Estuaries
}

Olivier Rouxel $^{1}$, Edward Sholkovitz ${ }^{1}$, Matthew Charette ${ }^{1}$ and Katrina J. Edwards ${ }^{1,2}$

${ }^{1}$ Woods Hole Oceanographic Institution, Marine Chemistry \& Geochemistry Dept., Woods Hole, MA 02543

${ }^{2}$ Department of Biological Sciences, University of Southern California, Los Angeles, CA 900890371

Manuscript in revision to Geochim. Cosmochim. Acta

Corresponding author

Olivier Rouxel

Woods Hole Oceanographic Institution

Marine Chemistry \& Geochemistry Dept., MS\#25

Woods Hole, MA 02543

Office: (508) 289-3655

Fax: (508) 457-2013

orouxel@whoi.edu 


\section{Abstract}

Dissolved $\mathrm{Fe}$ concentrations in subterranean estuaries, like their river-seawater counterparts, are strongly controlled by non-conservative behavior during mixing of groundwater and seawater in coastal aquifers. Previous studies at a subterranean estuary of Waquoit Bay on Cape Cod, USA demonstrate extensive precipitation of groundwater-borne dissolved ferrous iron and subsequent accumulation of iron oxides onto subsurface sands. Waquoit Bay is thus an excellent natural laboratory to assess the mechanisms of Fe-isotope fractionation in redoxstratified environments and determine potential Fe-isotope signatures of groundwater sources to coastal seawater. Here, we report Fe isotope compositions of iron-coated sands and porewaters beneath the intertidal zone of Waquoit Bay. The distribution of pore water Fe shows two distinct sources of Fe: one residing in the upward rising plume of Fe-rich groundwater and the second in the salt-wedge zone of pore water. The groundwater source has high $\mathrm{Fe}(\mathrm{II})$ concentration consistent with anoxic conditions and yield $\delta^{56} \mathrm{Fe}$ values between 0.3 and $-1.3 \%$. In contrast, sediment porewaters occurring in the mixing zone of the subterranean estuary have very low $\delta^{56} \mathrm{Fe}$ values down to $-5 \%$. These low $\delta^{56} \mathrm{Fe}$ values reflect $\mathrm{Fe}$-redox cycling and result from the preferential retention of heavy Fe-isotopes onto newly formed Fe-oxyhydroxides. Analysis of Feoxides precipitated onto subsurface sands in two cores from the subterranean estuary revealed strong $\delta^{56} \mathrm{Fe}$ and $\mathrm{Fe}$ concentration gradients over less than $2 \mathrm{~m}$, yielding an overall range of $\delta^{56} \mathrm{Fe}$ values between -2 and 1.5\%o. The relationship between Fe concentration and $\delta^{56} \mathrm{Fe}$ of Fe-rich sands can be modeled by the progressive precipitation of Fe-oxides along fluid flow through the subterranean estuary. These results demonstrate that large-scale Fe isotope fractionation (up to $5 \%$ ) can occur in subterranean estuaries, which could lead to coastal seawater characterized by very low $\delta^{56} \mathrm{Fe}$ values relative to river values. 


\section{Introduction}

Iron is a particle reactive trace metal present at extremely low concentrations in the upper ocean $(<1 \mathrm{nM})$ (e.g. Wu et al., 2001; Boyle et al., 2005) and is now recognized as a limiting nutrient in large regions of world's ocean and in certain coastal waters (Martin, 1990; Hutchins et al., 1999; Archer and Johnson, 2000; Boyd et al., 2000). The main sources of dissolved Fe into the ocean are atmospheric deposition, input from rivers, re-suspended sediment and pore water along continental shelves and hydrothermal vents (e.g. Wells et al., 1995; Elderfield and Schultz, 1996; Johnson et al., 1999). In contrast to the interior of the oceans, marine sediments and rivers are important sources of iron to the water column of coastal systems (e.g., Hutchins et al., 1999; Johnson et al., 1999; Elrod et al., 2004;. Mayer, 1982; Powell and Wilson-Finelli, 2003; Jickells et al., 2005; Buck et al., 2007; Ussher et al., 2007).

The stable isotope composition of Fe can provide valuable insights into the sources of $\mathrm{Fe}$ and $\mathrm{Fe}$ biogeochemical cycles in marine and terrestrial environment. In particular, significant fractionation of $\mathrm{Fe}$ isotopes has been demonstrated during partial oxidation and reduction reactions, suggesting that Fe isotopes are useful tracers of Fe redox cycling (Beard et al., 2003b; Johnson et al., 2004; Rouxel et al., 2005; Staubwasser et al., 2005; Teutsch et al., 2005; Severmann et al., 2006; Anbar and Rouxel, 2007; de Jong et al., 2007). These redox processes include dissimilatory Fe(III) reduction (Beard et al., 1999; Beard et al., 2003a; Crosby et al., 2007; Icopini et al., 2004), anaerobic photosynthetic Fe(II) oxidation (Croal et al., 2004), abiotic Fe(II) oxidation and precipitation of ferric hydroxides (Bullen et al., 2001; Balci et al., 2006), and sorption of aqueous Fe(II) onto ferric hydroxides (Icopini et al., 2004; Teutsch et al., 2005). The largest equilibrium isotope fractionations of around 3\%o have been observed and theoretically calculated between co-existing Fe(III) and Fe(II) aqueous species (Johnson et al., 2002; Welch et al., 2003; Anbar et al., 2005).

Our knowledge of the $\mathrm{Fe}$ isotope composition of $\mathrm{Fe}$ sources to the ocean remains incomplete. Fe carried by rivers, including both soluble, colloidal and particulate fractions, has $\delta^{56} \mathrm{Fe}$ values ranging between $\sim 0$ and $-1 \%$, suggesting that riverine $\mathrm{Fe}$ is isotopically light relative to igneous rocks (Fantle and De Paolo, 2004; Bergquist and Boyle, 2006). Iron isotope compositions of marine pore fluids from the California continental reveal a relatively large Fe isotope fractionation during early diagenetic processes, with $\delta^{56} \mathrm{Fe}$ values ranging from -3 to 
$+0.4 \%$ (Severmann et al., 2006). Hence, the intense cycling of Fe between oxidized and reduced

species in the upper few $\mathrm{cm}$ of coastal sediments can lead to the release of low $\delta^{56} \mathrm{Fe}$ iron from sediments to the water column (Staubwasser et al., 2005; Severmann et al., 2006).

Studies indicate that groundwater may contribute significantly to dissolved chemical species to the oceans (Moore, 1999) and, in one recent case, may also represent a large source of dissolved Fe to the coastal ocean (Windom et al., 2006). The magnitude of groundwater fluxes is influenced by biogeochemical processes occurring in the subterranean estuary, defined as the mixing zone between groundwater and seawater in a coastal aquifer. Dissolved Fe concentrations in subterranean estuaries, like their river-seawater counterparts, are strongly controlled by nonconservative (removal) behavior during mixing of river water and seawater (Sholkovitz, 1976; Boyle et al., 1977). However, a unique feature of subterranean estuaries is that the removal of Fe and other nutrients is mainly controlled by the redox characteristics of the fresh and saline groundwater (Slomp and Van Cappellen, 2004). In particular, the recent discovery of an "Iron Curtain" in the subterranean estuary of Waquoit Bay on Cape Cod, USA demonstrates extensive precipitation of groundwater-borne dissolved ferrous iron and subsequent accumulation of iron oxides onto subsurface sands at the groundwater-seawater interface (Charette and Sholkovitz, 2002; Charette et al., 2005; Charette and Sholkovitz, 2006). Waquoit Bay is thus an excellent natural laboratory to assess the Fe-isotope composition of the groundwater input in a coastal zone and to evaluate if the iron flux from subterranean estuaries has a unique Fe isotope signature that is distinct from other coastal iron sources.

Here, we report a comprehensive study that demonstrates that the precipitation of iron oxides and redox-driven diagenetic reactions in subterranean estuaries produce large-scale variations of $\mathrm{Fe}$ isotopes in both sediments and pore water. This approach provides important constraints on the mechanisms of Fe-isotope fractionation during Fe redox cycling. In particular, we aim to evaluate the relative effects of $\mathrm{Fe}$-isotope fractionation associated with oxidative $\mathrm{Fe}$ precipitation vs. reductive Fe-dissolution pathways in a redox stratified environment.

\section{Materials and Setting}

Waquoit Bay is a shallow estuary located on the south shoreline of Cape Cod, MA, USA. A significant portion of the freshwater input into the bay occurs as submarine discharge of 
groundwater (Charette et al., 2001) which is mostly restricted to a narrow ( 25m-wide) band along the head of the bay (Michael et al., 2003) (Fig. 1). Freshwater flowing downgradient from the water table may either discharge at the shore or flow directly under the beach into the sea. The hydraulic gradient that drives freshwater toward the sea along the fresh-saline groundwater interface also drives saltwater shoreward, creating a saltwater circulation cell (Michael et al., 2005; Moore, 1999). The hydraulic gradient is influenced by tides and rainfall, leading to hourly (Sholkovitz et al., 2003), seasonal (Michael et al., 2003), and interannual variability in groundwater discharge rates at this location. Topography also exerts a significant control on the location and flux of groundwater discharge at Waquoit Bay (Mulligan and Charette, 2006). While these factors can modulate the peak concentration and vertical/horizontal position of the dissolved Fe plumes in Waquoit Bay, six years of repeated sampling shows the same general features in the Fe distributions as reported in this paper (Charette et al., 2005).

Previous studies of the subterranean estuary of Waquoit Bay (Charette and Sholkovitz, 2002, 2006; Charette et al., 2005) have reported on element cycling of Fe, Mn, Ba, P and U in the permeable sediments and pore water. A series of sediment cores, ranging from 1.1 to $2.0 \mathrm{~m}$ in length were collected at the head of Waquoit Bay in April 2001 using a vibracoring technique (Charette and Sholkovitz, 2002). The pore water within the permeable sands of these cores drained away during the extrusion and sectioning activities. Hence, our solid phase data of Fe isotopes for these cores are not accompanied by pore-water data. Of the five recovered cores, Cores 2 and 3 have been selected for this study based on their location relative to the source of groundwater in the bay (Fig. 1). Core 2 is located near the piezometer transect A-A' in Figure 1 whereas Core 3 is located near piezometer \#4, about $50 \mathrm{~m}$ apart. The recovered lengths for cores 2 and 3 were 175 and $169 \mathrm{~cm}$, respectively. The most outstanding visual feature of these cores is the color changes that occur over a transition zone of many tens of centimeters. Core 2 changes from gray to dark red coating at a depth of $\sim 85 \mathrm{~cm}$; this color change reflects predominantly the deposition of ferrihydrite (64\%) with goethite (26\%) and lepidocrocite (10\%). Core 3 changes from gray to red to orange at a depth of $\sim 30 \mathrm{~cm}$ and has the largest amount of lepidocrocite (19\%) whereas goethite and ferrihydrite represent 44 and 37\% respectively (Charette et al., 2005). We also analyzed two types of "background" sediments (1) surface beach sand from the head of Waquoit Bay near the coring sites, and (2) offsite sand collected from a Vineyard Sound beach located $10 \mathrm{~km}$ from Waquoit Bay. All types of sediments (surface and deep) have similar size 
distribution and contain greater than $95 \%$ sand (mainly quartz with trace amounts of plagioclase and clinopyroxene, amphiboles and mica) and less than 5\% silt and clay.

A piezometer was used to obtain a two dimensional distribution of the porewater composition at the head of the bay along a $17 \mathrm{~m}$ transect. Field sampling methods and porewater chemistry are presented in detail in previous studies (Charette and Allen, 2006; Charette and Sholkovitz, 2006). The piezometer consists of a screened port at the end of a thin probe which can be pushed down into the beach sands. Ground water is pumped to the surface through plastic tubing. Slow pumping and immediate filtration using syringes keeps the ambient air out of the samples which minimizes the oxidation of dissolved Fe (II) to particulate Fe (III) oxides prior to acidification and storage. Each profile required 4 to $8 \mathrm{~h}$ of sampling, and the complete transect covered 17 days (7 June to 3 July 2002). Hence, the pore-water data do not represent synchronous distributions of the measured parameters. The salinity distribution along the piezometer transect A-A' (Fig. 1) is presented in Figure 2 and shows that there is a well-defined subterranean estuary beneath the head of the Bay. Fresh groundwater flows across a narrow seepage face parallel to the shoreline. Two distinct sources of high dissolved Fe have been identified (Fig. 2). One source resides in the upward rising plume of Fe-rich freshwater and the second source lies in the saltwedge zone of mid to high salinity pore water. The second source of dissolved Fe, where pore water concentrations reach up to $75 \mu \mathrm{M}$ in Piezometer\#8 along the transect A-A' (Fig. 2) and up to $500 \mu \mathrm{M}$ in Piezometer \#4 ( 50m away), result from chemical diagenesis typical of that found in reducing marine sediments where microbial activity leads to the reduction of Fe oxide (Froelich et al., 1979). Pore water data show that sulfate reduction is not occurring in the salt wedge section that contains high levels of reduced Fe and Mn. Hence, the production of sulfides is not an important part of the redox-driven cycling of Fe (Charette and Sholkovitz, 2006). The lack of sulfide formation in porewater, together with dissolved $\mathrm{O}_{2}$ concentration less down to 0.5 $\mathrm{mg} / \mathrm{L}$, suggest mostly $\mathrm{O}_{2}$-deficient but not anoxic conditions within the subterranean estuary. Representative samples of groundwater and Fe(II)-rich pore waters with Fe concentration between 30 and $490 \mu \mathrm{M}$ were selected for Fe isotope measurements (Fig. 2).

It is important to note the large difference in scale between the sediment cores (maximum $1.8 \mathrm{~m}$ in length) and porewater samples that extend up to $8 \mathrm{~m}$ into the sediment beneath the head of Waquoit Bay (Figure 2). Hence, sediment core geochemistry cannot be directly link to porewater geochemistry. Because the Fe concentrations continue to increase toward the bottom of 
the sediment cores, the full vertical extent of the iron curtain sediments was not entirely known at the time of collection. Recently, a set of longer $(7 \mathrm{~m})$ sediment cores from this location were collected. Fe (hydr)oxide analysis of the sediment revealed the existence of two iron curtains: (1) a shallow one, approximately $2 \mathrm{~m}$ in the vertical, likely associated with oxidation of Fe from the freshwater Fe plume, and (2) a deeper, $1 \mathrm{~m}$ zone of high Fe located just above the mid-high salinity Fe maximum (Gonneea et al., 2007).

\section{Analytical method}

Core sediments and beach sands were air dried and hand-sieved through a polypropylene mesh with a nominal retention diameter of $1 \mathrm{~mm}$. The concentration of Fe and $\mathrm{Mn}$ in the sieved sediments, along with their associated $\mathrm{P}, \mathrm{Ba}, \mathrm{U}$ and $\mathrm{Th}$ concentrations, have been reported previously (Charette et al., 2005; Charette and Sholkovitz, 2006) using a selective dissolution protocol (Hall et al., 1996). This protocol was designed to selectively dissolve "amorphous" iron oxides followed by "crystalline" $\mathrm{Fe}$ (hydr)oxides using reductive solutions of $0.25 \mathrm{M}$ hydroxylamine hydrochloride in $0.05 \mathrm{M} \mathrm{HCl}$ and $1 \mathrm{M}$ hydroxylamine hydrochloride in $25 \%$ glacial acetic acid respectively. The sum of these two leaches is referred to a "total oxide" composition and data are reported in Table 3.

Because reductive Fe-(hydr)oxides dissolution may fractionate Fe-isotopes during incomplete reduction of $\mathrm{Fe}(\mathrm{III})$ to $\mathrm{Fe}(\mathrm{II})$ (Icopini et al., 2004), we preferred using concentrated acid dissolution that prevent Fe-isotope fractionation (Skulan et al., 2002). Fe-oxides, coating quartz sands, were dissolved in PTFE beaker using ultra-pure grade $6 \mathrm{~N} \mathrm{HCl}$ on hot plate for 24 hours at approximately $80^{\circ} \mathrm{C}$. $10 \mathrm{~mL}$ of $6 \mathrm{~N} \mathrm{HCl}$ with $50 \mu \mathrm{l}$ of ultrapure $\mathrm{H}_{2} \mathrm{O}_{2}$ were used for about $500 \mathrm{mg}$ of sands. Because the sediments at Waquoit Bay are primarily composed of quartz sand coated with various Fe-oxide phases and contain only minor silicate minerals, Fe concentrations determined using our strong acid leach method agreed well with total Fe concentration using the selective dissolution protocol reported in Charette et al. (2005). Sample purification for mass spectrometry analysis has been undertaken by ion-exchange chromatography in a clean room environment following previous protocols (Beard et al., 2003a; Rouxel et al., 2005). After centrifugation and separation of $6 \mathrm{~N} \mathrm{HCl}$ by pipetting, a precise solution volume, corresponding to not more than $100 \mu \mathrm{g}$ of Fe, was purified on Bio-Rad AG1X8 anion resin (2.5 mL wet bed). After 
$30 \mathrm{~mL}$ of $6 \mathrm{~N} \mathrm{HCl}$ was passed through the column to remove the matrix, $20 \mathrm{~mL}$ of $0.12 \mathrm{~N} \mathrm{HCl}$ was used to elute Fe. Eluted solution was then evaporated to dryness and dissolved with $2 \% \mathrm{HNO}_{3}$ for mass spectrometry analysis.

In treating the pore water samples, aliquots are evaporated and then purified in the same manner as for solid samples. No more than $15 \mathrm{~mL}$ of the water samples are dried down in PTFE beakers with $1 \mathrm{~mL}$ of concentrated $\mathrm{HNO}_{3}$. This step is repeated. The maximum operational volume for saline water reflects the high load of salts that prevent evaporating larger volume of waters without subsequent problems during chromatography separation. After evaporation, the residues of the water samples are dissolved with $5 \mathrm{~mL} 6 \mathrm{~N} \mathrm{HCl}$ with trace of $\mathrm{H}_{2} \mathrm{O}_{2}$ and subsequently purified through ion-exchange chromatography.

The Fe isotope composition was determined with a Finnigan Neptune multicollector inductively coupled plasma mass spectrometry (MC-ICPMS) operated at Woods Hole Oceanographic Institution (WHOI). The Neptune instrument permits high precision measurement of Fe isotope ratios without argon interferences using high-mass resolution mode (Malinovski et al., 2003; Weyer and Schwieters, 2003; Arnold et al., 2004). Mass resolution power of about 8000 (medium resolution mode) was used to resolve isobaric interferences, such as $\mathrm{ArO}$ on ${ }^{56} \mathrm{Fe}$, $\mathrm{ArOH}$ on ${ }^{57} \mathrm{Fe}$, and $\mathrm{ArN}$ on ${ }^{54} \mathrm{Fe}$.

Instrumental mass bias is corrected using $\mathrm{Ni}$ isotopes as internal standard. This method, which has been proved to be reliable for the Neptune instrument, involves deriving the instrumental mass bias from simultaneously measuring a Ni standard solution (Malinovski et al., 2003; Poitrasson and Freydier, 2005). We also used the "sample-standard bracketing" technique to correct for instrumental mass discrimination by normalizing Fe isotope ratios to the average measured composition of the standard that was run before and after the sample (Belshaw et al., 2000; Beard et al., 2003a; Rouxel et al., 2003). Fe isotope compositions are reported relative the Fe-isotope standard IRMM-14 using the following notation:

$$
\begin{gathered}
\delta^{56} \mathrm{Fe}=1000 *\left[\left({ }^{56} \mathrm{Fe} /{ }^{54} \mathrm{Fe}\right)_{\text {sample }}\left({ }^{56} \mathrm{Fe} /{ }^{54} \mathrm{Fe}\right)_{\text {IRMM-14 }}-1\right] \\
\delta^{57} \mathrm{Fe}=1000 *\left[\left({ }^{57} \mathrm{Fe} /{ }^{54} \mathrm{Fe}\right)_{\text {sample }} /\left({ }^{57} \mathrm{Fe} /{ }^{54} \mathrm{Fe}\right)_{\text {IRMM-14 }}-1\right] \\
{ }^{53} \mathrm{Cr},{ }^{54} \mathrm{Fe},{ }^{56} \mathrm{Fe},{ }^{57} \mathrm{Fe},{ }^{58} \mathrm{Fe}+{ }^{58} \mathrm{Ni}{ }^{60} \mathrm{Ni} \text {, and }{ }^{61} \mathrm{Ni} \text { isotopes were counted on the Faraday cups }
\end{gathered}
$$

using the high mass resolution mode. Although quantitatively separated during analysis, $\mathrm{Cr}$, which interferes with ${ }^{54} \mathrm{Fe}$, was monitored during each $\mathrm{Fe}$ isotope measurements and found to identical of background levels. Baseline corrections were made before acquisition of each data 
block by completely deflecting the ion beam. All isotope data reported in this study were analyzed at least twice using both techniques (i.e. Ni doping and standard-sample bracketing) and the internal precision of the data are given at 95\% confidence levels based on the standard deviation calculated on duplicates.

Purified samples of Fe-oxide-coated sands were diluted to $1.5 \mathrm{ppm}$ of $\mathrm{Fe}$ and $\mathrm{Ni}$ and introduced into the plasma using a double quartz spray chamber system (cyclonic and double pass) and a microconcentric PFA nebulizer operating at a flow rate of about $100 \mu 1 / \mathrm{min}$. Purified water samples were analyzed using a desolvation nebulizer (Cetac Apex) and X-cones (ThermoFinnigan) to improve the sensitivity of the Neptune (Schoenberg and Von Blanckenburg, 2005).

Based on over 50 analyses - dissolution, purification and ICP-MS measurement - of an internal standard (BHVO-1, a Hawaiian basalt), we have obtained an average of $\delta^{56} \mathrm{Fe}$ values at 0.10 with a precision of $0.09 \%$ o $(2 \sigma)$. We evaluated the accuracy of measuring Fe isotopes in saline water samples through the analysis of $\mathrm{Fe}$ isotope composition of artificial samples corresponding to seawater-like matrix doped with Fe standard. Procedural blanks, including evaporation/dissolution steps and ion exchange purification are below $5 \mathrm{ng}$. As presented in Table 1, a precision of $0.15 \%$ can be achieved for saline water samples as low as $5 \mu \mathrm{M}$ and probably lower.

\section{Results}

\subsection{Fe-isotope composition of groundwater and brackish porewaters.}

In a previous study, Charette and Sholkovitz (2006) reported Fe concentrations in porewater ranging from less than $1 \mu \mathrm{M}$ to up to $500 \mu \mathrm{M}$ for the whole salinity range of the subterranean estuary. A subset of twenty-six porewater samples has been selected for this study based on their Fe concentration and location within the subterranean estuary. Exact location of these porewater samples relative to the subterranean estuary are presented in Figure 2 together with corresponding Fe-concentration and salinity.

We selected groundwater samples with salinity $<0.4$ along the piezometer transect $(\mathrm{Pz} \# 6$, 7 and 10) to characterize the Fe-isotope composition of Fe(II) in the seaward-moving plume of freshwater feeding the subterranean estuary. Results show a range of $\delta^{56} \mathrm{Fe}$ values between 0.44 
and $-0.8 \%$ o (Table 2) with higher $\delta^{56} \mathrm{Fe}$ values found in shallower sections whereas lower $\delta^{56} \mathrm{Fe}$ values are found deeper near the salinity gradient within the subterranean estuary.

We also selected brackish porewater samples with salinity between 19 and 29 and Feconcentrations between 40 and $500 \mu \mathrm{M}$ and obtained $\delta^{56} \mathrm{Fe}$ values ranging from $-4.8 \%$ o to $0.22 \%$ (Table 2). It is important to note that porewater having a salinity between 19 and 27 (e.g. Piezometer \#3 and \#4) display the largest Fe-isotope fractionation suggesting that most of the fractionation of Fe-isotopes in porewater is observed at the interface between the two major sources of reduced $\mathrm{Fe}$ in the subterranean estuary. This range of $\delta^{56} \mathrm{Fe}$ values is the largest reported so far in natural systems and indicates that Fe redox cycling across the salinity gradient at Waquoit is able to produce extreme Fe-isotope fractionation in porewater.

\subsection{Fe-isotope composition of permeable sediments.}

As presented in Figure 3 and Table 3, Fe oxide coated sands in Core \#2 have Fe concentrations ranging from 500 to $8000 \mathrm{ppm}$ and $\delta^{56} \mathrm{Fe}$ values decreasing upward from $\sim 1.5 \%$ at $140 \mathrm{~cm}$ to $0 \%$ near the surface. The $\delta^{56} \mathrm{Fe}$ gradient of $1.5 \%$, over $1.4 \mathrm{~m}$ of section mirrors the Fe concentration gradient. The Fe concentration in Core 3 increases downward from 900 ppm to more than $7500 \mathrm{ppm}$ at $100 \mathrm{~cm}$. In contrast to mostly positive $\delta^{56} \mathrm{Fe}$ values in Core 2 , Core 3 oxides have systematically negative $\delta^{56} \mathrm{Fe}$ values. Core 3 also exhibits a well defined minimum $\delta^{56} \mathrm{Fe}(-1.8 \%)$ in the mid-depth section $(45-55 \mathrm{~cm})$ while maximum $\delta^{56} \mathrm{Fe}$ values (between -0.2 and $-0.4 \%$ ) occur at the top and bottom $(120 \mathrm{~cm})$ of the core $\left(\mathbf{F i g}\right.$. 3). The overall range of $\delta^{56} \mathrm{Fe}$ values $\sim 1.6 \%$ in Core 3 is however similar to Core 2. Two types of "background" sediments (surface beach sand at Waquoit Bay and offsite sand collected 10km from Waquoit Bay) were also analyzed and results show a restricted range of Fe-isotope composition clustered at $0 \%$ and Fe concentrations between 300 and 430 ppm.

Because a vibra-core was used to recover sediment cores, it was not possible to sample corresponding pore water. Although Core 2 and 3 were recovered in the proximity of piezometer \#8 and \#4 respectively (Fig. 1), we only have Fe-isotope composition of pore water deeper in the section. However, we note that generally negative $\delta^{56} \mathrm{Fe}$ values in Fe-oxides in Core 3 (down to $1.8 \%$ ) are consistent with the highly negative values found in Piezometer $\# 4$ ( $\delta^{56}$ Fe values down to $-2.4 \%$ at 4 meters depth). Likewise, positive $\delta^{56} \mathrm{Fe}$ values in Core 2 are consistent with higher 
$\delta^{56} \mathrm{Fe}$ values in Piezometer $\# 8$ ( $\delta^{56} \mathrm{Fe}$ between 0.22 and $-0.31 \%$ from 0.6 to $0.9 \mathrm{~m}$ depth). Hence, the major difference between Core 2 (i.e. mostly positive $\delta^{56} \mathrm{Fe}$ values) and Core 3 (i.e. mostly negative $\delta^{56} \mathrm{Fe}$ values) is, to a first approximation, the result of different initial $\delta^{56} \mathrm{Fe}$ values for pore water $\mathrm{Fe}$ (II) for each cores The difference between $\delta^{56} \mathrm{Fe}$ values in Core 2 and 3 that are about $50 \mathrm{~m}$ apart as well as the variability of $\delta^{56} \mathrm{Fe}$ values of up to $1.5 \%$ within each core demonstrate large variations of porewater $\delta^{56} \mathrm{Fe}$ values over several centimeters to meters at the head of the Bay. The significance of these variations is discussed in the following section.

\section{Discussion}

\subsection{Freshwater source at Waquoit Bay}

Cape Cod ground burden consists mainly of coarse-grained sand, and as such rain precipitation infiltrates the sediments and recharges subsurface aquifers. Hence, groundwater is a major source of freshwater to Waquoit Bay in addition to the two rivers that drain into it (Charette et al., 2001). The source of Fe(II) we have measured in the groundwater is uncertain, but likely derives from rainwater circulating through soils and local freshwater ponds. Previous measurements that have been made on dissolved Fe in rivers, including both soluble and colloidal fractions, have shown variable $\delta^{56} \mathrm{Fe}$ values ranging between $\sim 0$ and $-1 \%$. This suggests that dissolved Fe is isotopically light relative to igneous rocks (Fantle and De Paolo, 2004; Bergquist and Boyle, 2006). Measurements on the Fe-isotope compositions of pore water in soils also indicate that mineral dissolution in the presence of Fe-chelating organic ligands and Fe-reducing bacteria preferentially releases light Fe from silicates and Fe-oxides (Brantley et al., 2001; Brantley et al., 2004; Emmanuel et al., 2005). Teutch et al. (2005) obtained $\delta^{56} \mathrm{Fe}$ values of -0.4 $\pm 0.1 \%$ for anoxic groundwater which are lighter than the sediment leach for $\mathrm{Fe}$ (III) $(0.16 \pm 0.05$ $\%$ ). These values have been interpreted as reflecting a slight fractionation (only $0.3 \%$ ) during microbial mediated reductive dissolution of Fe-oxyhydroxides present in the aquifer.

Our measurements of $\delta^{56} \mathrm{Fe}$ values in the groundwater at Waquoit Bay, between 0.44 and $-0.8 \%$, are thus similar to the values that have been obtained for dissolved $\mathrm{Fe}$ in several other systems. The lowest $\delta^{56} \mathrm{Fe}$ values down to $-0.8 \%$ could be explained by either reductive dissolution of Fe(III)-oxyhydroxides (Beard et al., 2003a; Icopini et al., 2004; Balci et al., 2006) or organic-ligand promoted silicate dissolution (Brantley et al., 2004) in soil environments. The 
origin of the positive $\delta^{56} \mathrm{Fe}$ values (up to $0.44 \%$ ) is however less clear. It is possible that they are due to quantitative reductive dissolution of isotopically enriched Fe-oxides in subsurface sediments beneath the head of the Bay. It is also possible that run-off freshwater may be characterized by slightly positive $\delta^{56} \mathrm{Fe}$ values $\sim 0.4 \%$ as recently reported in local rivers (Escoube et al., 2007). In both cases, $\delta^{56} \mathrm{Fe}$ values in groundwater are controlled by the mixing between shallow and deeper sources with positive and negative $\delta^{56} \mathrm{Fe}$ values respectively. Based on these results, we constrain the $\delta^{56} \mathrm{Fe}$ value of the freshwater source of $\mathrm{Fe}(\mathrm{II})$ to Waquoit Bay to be around $-0.15 \pm 0.5 \%$ which is, on average, close to bulk $\delta^{56} \mathrm{Fe}$ values for soils and lithogenic Fe-sources (Emmanuel et al., 2005; Poitrasson and Freydier, 2005).

\subsection{Fe-isotope systematics of Fe-oxide coated sands}

As reported by Charette and Sholkovitz (2002), the deeper sections of Cores 2 and 3 are characterized by large amounts of Fe oxides (ferrihydrite, lepidocrocite and goethite) that precipitate on quartz sand. Note that the salinity gradient along Piezometers $\# 8$ and $\# 4$ is located in the vicinity of Core 2 and 3 respectively (Table 2). This implies that the source of Fe to these sediment cores is derived from $\mathrm{Fe}(\mathrm{II})$-rich brackish pore waters. A "background" $\mathrm{Fe}$ oxyhydroxide component in sand is also anticipated in Core 2 and 3 because the analysis of two surface beach sand samples, away from any groundwater sources, yielded Fe concentration betweens 300 and $430 \mathrm{ppm}$ (Table 3). This "background" Fe-oxyhydroxide component has a restricted range of $\mathrm{Fe}$-isotope composition clustered at $0 \%$. Although the source of $\mathrm{Fe}$ oxyhydroxide in coastal area may be multiple (e.g. detrital, hydrogeneous, diagenetic sources), beach sands remote from local groundwater sources tend to have homogeneous Fe concentrations and $\delta^{56} \mathrm{Fe}$ values near $0 \%$. Hence, two major components of $\mathrm{Fe}$ are expected in sediment Core 2 and 3: (1) background Fe-oxides with $\delta^{56} \mathrm{Fe}$ values near $0 \%$ and concentrations below 500ppm; and (2) and Fe-oxides formed during the upward transport and oxidation of $\mathrm{Fe}$ (II)-rich pore waters from saline zone.

An important question to address is whether these variable $\delta^{56} \mathrm{Fe}$ values and $\mathrm{Fe}$ concentrations through the sediment cores at Waquoit Bay result from mixing effects between lithogenic Fe-oxides and diagenetic (i.e. derived from Fe-rich porewater) Fe-oxides or result from in-situ Fe-isotope fractionation during oxidative Fe precipitation. The potential relationships 
between $\mathrm{Fe}$ concentrations and $\delta^{56} \mathrm{Fe}$ values of $\mathrm{Fe}$ oxides in the case of mixing between lithogenic and diagenetic Fe-oxides are presented in Figure 4. The model assumes $\delta^{56} \mathrm{Fe}$ values for lithogenic at $0 \%$ and diagenetic Fe-oxides having $\delta^{56} \mathrm{Fe}$ values similar to those measured in the deeper section of each core. The results suggest that Fe-isotope composition of both sediment cores cannot be simply explained by a binary mixing between these two sources. In the case of Core 2, the mixing between lithogenic and isotopically enriched Fe-oxides does not account for the near linear correlation between Fe concentrations and $\delta^{56} \mathrm{Fe}$ values. Similarly, in the case for Core 3, the strong curvature observed between $\mathrm{Fe}$ concentrations and $\delta^{56} \mathrm{Fe}$ values argue against simple mixing effects.

The correlation between Fe concentration and $\delta^{56} \mathrm{Fe}$ values in Core 2 and bottom half of Core 3 is consistent with results reported by Bullen et al. (2001) and Teutsch et al. (2005). Bullen et al. (2001) reported abiotic Fe isotope fractionation during precipitation of isotopically enriched Fe-oxyhydroxides from Fe-rich spring water, resulting in lighter aqueous Fe(II) and lower Fe in the remaining dissolved Fe(II). Teutch et al. (2005) measured the evolution of the Fe-isotope composition of $\mathrm{Fe}(\mathrm{II})$-rich reduced groundwater during injection of oxygen-containing water. They show that the adsorption of Fe(II) onto newly formed Fe(III)-oxyhydroxides yields a very light groundwater component with $\delta^{56} \mathrm{Fe}$ values as low as $-3 \%$, indicating that heavier $\mathrm{Fe}(\mathrm{II})$ is preferentially adsorbed to the newly formed $\mathrm{Fe}(\mathrm{III})$-oxyhydroxides surfaces. These field observations are consistent with experimental studies showing a preferential enrichment of heavy Fe-isotopes associated with the formation of Fe-oxyhydroxides (Welch et al., 2003; Croal et al., 2004; Balci et al., 2006). Our results also suggest that a similar process is affecting the Fe-isotope composition of sediment cores at the head of Waquoit Bay.

In order to test the hypothesis that the fractionation of Fe-isotopes in iron oxides is controlled by partial oxidation of $\mathrm{Fe}(\mathrm{II})$-rich porewater upon mixing with seawater, we have formulated a simple mathematical model for the evolution of Fe-isotopes in sediments. The numerical model is described in more detail in Appendix $\mathbf{A}$ and results are presented below for Core \#2 and \#3. In this model, it is considered that $\mathrm{Fe}(\mathrm{II})$ is progressively oxidized within the uppermost $\sim 2 \mathrm{~m}$ of sediments, limited by oxic coastal seawater and Fe(II)-rich porewater (Fig. 5). Hence, for each depth level, Fe concentration and isotope composition in sediments will be controlled by the extent of Fe-oxyhydroxide precipitation and input from underlying porewater as 
well as and the relative contribution of «background $" \mathrm{Fe}$-oxides having $\delta^{56} \mathrm{Fe}=0 \%$. In this model, the theoretical relationship between Fe concentration and Fe-isotope composition of sediments for each depth is calculated using advection-reaction model during partial $\mathrm{Fe}(\mathrm{II})$ oxidation and Fe-oxyhydroxide precipitation. Variable parameters of this model include: i) initial $\delta^{56} \mathrm{Fe}_{\mathrm{i}}$ composition of porewater $\mathrm{Fe}(\mathrm{II})$; ii) $\mathrm{Fe}(\mathrm{II})$ oxidation rate; iii) $\mathrm{Fe}$-isotope fractionation factor $\alpha$ between $\mathrm{Fe}(\mathrm{II})$ and Fe-oxyhydroxides. The rate of $\mathrm{Fe}(\mathrm{II})$ oxidation cannot be easily determined at each depth since $\mathrm{O}_{2}$ concentrations are not available along the sediment sections. Nevertheless, in the oxygen deficient conditions in sediment porewater of Waquoit Bay, with $\mathrm{O}_{2}$ $<5 \mu \mathrm{M}$ and seawater-like $\mathrm{pH}$, temperature and salinity, the $\mathrm{Fe}$ (II) oxidation rate is expected to be less than $\sim 0.3$ day $^{-1}$ (Millero et al., 1987). The mean groundwater discharge for the head of Waquoit Bay is considered constant at $8 \mathrm{~cm} \mathrm{~d}^{-1}$ following the estimation by Abraham et al. (2003). It is however important to note that significant temporal variability of the groundwater discharge occurs in response to tidal cycles and seasonal or interannual precipitation variability. There is also evidence that the groundwater discharge is heterogeneously distributed along the head of Waquoit Bay with Core 3 located in area with higher groundwater flow than in Core 2 (Mulligan and Charette, 2006). Although a more complex numerical treatment of Fe-isotope systematics in sediment cores, one that integrates variable rates of $\mathrm{Fe}(\mathrm{II})$ oxidation, Fe-isotope fractionation factors and groundwater discharge (both vertically and horizontally) is possible, such a model is beyond our objectives for this paper.

\subsubsection{Core 2:}

Results for Core 2 are presented in Figure 4 and show that the relationship between Feconcentration and Fe-isotope composition can be modeled using a simple advection-reaction model during partial Fe(II) oxidation and Fe-oxyhydroxide precipitation. A best fit of the data is obtained using a solid-liquid fractionation factor $(\alpha)$ at 1.001 and initial $\delta^{56} \mathrm{Fe}$ values of $0.8 \%$. The pseudo-first-order rate constant of Fe(II) oxidation is set constant at $0.12 \mathrm{~d}^{-1}$ over the entire core section, which is consistent with suboxic conditions (Millero et al., 1987). The value around 1.001 for the fractionation factor indicate that the $\delta^{56} \mathrm{Fe}$ value of precipitated Fe-oxides is enriched in heavy isotopes by $1.0 \%$ relative to dissolved Fe(II) which is similar to those obtained for abiotic Fe oxidation (around 0.9\%o) (Bullen et al., 2001) and slightly lower than for bacterial Fe oxidation (around 1.5\%) (Croal et al., 2004). The initial $\delta^{56} \mathrm{Fe}_{i}$ value $(\sim 0.8 \%$ o) of porewater in 
Core 2 is however higher than maximum measured $\delta^{56} \mathrm{Fe}$ values in porewater from Piezometer \#8 ( $\delta^{56} \mathrm{Fe}$ between 0.22 and $-0.31 \%$ from 0.6 to $0.9 \mathrm{~m}$ depth). This discrepancy may be explained by the differences in sampling time (i.e. Core 2 was recovered in April 2001 whereas porewater samples were recovered between June and July 2002) and the fact that porewater composition may changes through time. It is also possible that higher porewater $\delta^{56} \mathrm{Fe}_{\mathrm{i}}$ values $(\sim 0.8 \%)$ are due to reductive dissolution of isotopically enriched Fe-oxides previously precipitated deeper in Core 2.

\subsubsection{Core 3:}

Results for Core 3 are presented in Figure 4 and the relationship between Feconcentration and Fe-isotope composition has been modeled using a similar advection-reaction model than for Core 2. Although the model reproduce the well defined minimum $\delta^{56} \mathrm{Fe}$ values (1.5 to $1.8 \%$ ) in the mid-depth section $(0.5-0.6 \mathrm{~m})$, a single best-fit model curve cannot be obtained using a constant $\mathrm{Fe}$ (II) oxidation rate over the entire section of Core 3. Using a solidliquid fractionation factor $(\alpha)$ at 1.0012, the lower section of Core 2 is best explained using $\mathrm{Fe}(\mathrm{II})$ oxidation rate at $0.25 \mathrm{~d}^{-1}$ whereas the upper section is best explained using higher Fe(II) oxidation rate at $0.4 \mathrm{~d}^{-1}$ (Fig. 4). These results suggest that Fe(II) oxidation rate increase upward, during mixing between $\mathrm{O}_{2}$-poor porewater and oxic seawater.

It is interesting to note that, although Fe-isotope values between Core 2 and 3 are different, similar process (i.e. partial $\mathrm{Fe}(\mathrm{II})$ oxidation during upward advection of Fe-rich porewater) can explain Fe-isotope values in both Cores. In particular, the curvature in Figure 4 between Fe concentration and $\delta^{56} \mathrm{Fe}$ values in Core 3 (i.e. minimum $\delta^{56} \mathrm{Fe}$ values at mid-depth) is explained by the cumulative effect of (1) preferential depletion in heavy Fe isotopes in porewater due to partial oxidation, producing negative $\delta^{56} \mathrm{Fe}$ values for $\mathrm{Fe}(\mathrm{III})$-oxides and (2) increase in $\delta^{56} \mathrm{Fe}$ values for $\mathrm{Fe}(\mathrm{III})$ due to mixing effects with "background" Fe-oxyhydroxides having $\delta^{56} \mathrm{Fe}$ values around $0 \%$. Because the bottom half of Core 3 has much higher Fe-oxide concentration than "background" sands, $\delta^{56} \mathrm{Fe}$ values are mostly affected by Fe-isotope fractionation during partial Fe(II) oxidation whereas the top half, with lower Fe-oxide concentration, suggest a prominent effect of physical mixture between porewater-precipitated and "background" Feoxyhydroxides. Similar mass balance consideration can be applied for Core 2 to explain the lack of curvature between $\mathrm{Fe}$ concentration and $\delta^{56} \mathrm{Fe}$ values in Figure 4. In this case, the precipitation 
of isotopically heavy Fe-oxyhydroxides at the bottom of the core produces isotopically lighter, but not strongly negative, Fe-oxyhydroxides at the top of the core. Hence, the presence of "background" Fe-oxyhydroxides at $\sim 0 \%$ through Core 2 doesn't have significant effects on the overall $\mathrm{Fe}$ concentration vs. $\delta^{56} \mathrm{Fe}$ relationship, except in the uppermost section of the Core.

\subsection{Fe-isotope composition of brackish porewaters}

Because the variability of $\delta^{56} \mathrm{Fe}$ values in groundwater (between 0.44 and $-0.8 \%$ ) is of second order compared to the large range of $\delta^{56} \mathrm{Fe}$ values up to $5 \%$ in brackish porewaters (i.e. salinity between 19 and 27) (Fig. 6), it is unlikely that the variations of $\delta^{56} \mathrm{Fe}$ values in brackish porewater is controlled by groundwater Fe-isotope composition. Charette and Sholkovitz (2006) and Spiteri et al. (2006) showed that a major fraction of iron in the ferrous-rich groundwater is oxidized within the freshwater end of subterranean estuary between Piezometers 6 and 3. Indeed, pore water pumped from piezometer 3 at a depth of $3 \mathrm{~m}$ contained suspended yellow particles that are nearly pure iron oxyhydroxides. Spiteri et al. (2006) investigated the effect of $\mathrm{O}_{2}$ and $\mathrm{pH}$ gradients on $\mathrm{Fe}$ (II) oxidation rates along a flow-line in the subterranean estuary of Waquoit Bay. Results show that the observed $\mathrm{O}_{2}$ gradient is not the main factor controlling oxidative precipitation. Rather it was shown that the $\mathrm{pH}$ gradient at the mixing zone of freshwater and seawater causes a $\sim 7$-fold increase in the rate of $\mathrm{Fe}$ (II) oxidation. In contrast, the enrichment of $\mathrm{Fe}(\mathrm{II})$ in the saline porewater end-member is the result of diagenetic reactions and reductive dissolution of $\mathrm{Fe}$ (III) oxides. Hence, we infer that the large Fe-isotope fractionation across the salinity gradient is due to successive redox reactions associated with the oxidative precipitation of dissolved ferrous $\mathrm{Fe}$ in the freshwater endmember and the reductive dissolution of Fe oxides at higher salinity.

However, an important question remains is whether the very low $\delta^{56} \mathrm{Fe}$ values in porewaters (between -2 and -5\%) are solely the result of diagenetic reduction of Fe-oxides or may also result from partial $\mathrm{Fe}(\mathrm{II})$ oxidation in subsurface environments, as previously demonstrated in section 5.2 on the sediment cores. It has been experimentally demonstrated that Fe isotope fractionations during $\mathrm{Fe}(\mathrm{III})$ reduction (e.g. DIR, dissimilatory iron reduction) are dependent on reduction rates (Beard et al., 2003a; Johnson et al., 2004; Icopini et al., 2004). At high reduction rates, rapid formation and sorption of $\mathrm{Fe}(\mathrm{II})$ to ferric oxide substrate produced fractionations as large as $-2.3 \%$ but this value corresponds to an extreme case. Hence, a 
fractionation of $-1.3 \%$ between biogenic Fe(II) and ferric oxide is more representative. Our results of Fe-isotope composition of saline porewaters $\left(\mathrm{S}>27\right.$, Fig. 7) show $\delta^{56} \mathrm{Fe}$ values ranging from 0.2 to $-1.8 \%$, which are consistent with, but do not necessarily prove, Fe-isotope fractionation by Fe-reducing bacteria. These variations are also consistent with $\delta^{56} \mathrm{Fe}$ values found in suboxic porewater of margin sediments (Staubwasser et al., 2005; Severmann et al., 2006) where diagenetic Fe-redox cycling at sediment-water interface produce isotopically depleted Fe(II) pool in porewater. Porewater samples with the highest Fe concentrations (Pz\#4), representing the end-member for diagenetically reduced $\mathrm{Fe}(\mathrm{II})$, yield $\delta^{56} \mathrm{Fe}$ values of only $-0.5 \%$ which are surprisingly similar to groundwater $\delta^{56} \mathrm{Fe}$ values (Fig. 7). This minimal fractionation may reflect either small fractionation factors during DIR due to specific environmental conditions for Fe-reducing bacteria or either limiting Fe(III) substrate availability (i.e. quantitative reduction of Fe(III) substrate). Considering the extent of Fe-isotope fractionation during DIR at around -1.2 to $-1.5 \%$ (Beard et al., 2003a; Icopini et al., 2004), it appears unlikely that DIR processes alone would produce $\delta^{56} \mathrm{Fe}$ values as low as $-5 \%$ in porewaters in intermediate salinity and lower Feconcentrations.

Uranium in oxic sea water is very soluble as its redox form is U(VI). In marked contrast, reducing conditions in pore water and ground water lead to U(IV) which is very particle reactive. Hence, reducing sediments are depleted in pore water $U$; upon the return of more oxic conditions, sedimentary $\mathrm{U}$ is oxidized to $\mathrm{U}(\mathrm{VI})$ species and $\mathrm{U}$ is rapidly released in porewater (Barnes and Cochran, 1990).. Because soluble U(VI) can be converted to insoluble U(IV) under conditions similar to those that favor the reduction of Fe(III) to Fe(II) (Cochran et al., 1986; Barnes and Cochran, 1990; Chaillou et al., 2002; Mcmanus et al., 2006), comparing U concentrations with $\delta^{56} \mathrm{Fe}$ values in porewaters may provide insight regarding the relative effect of oxidative $\mathrm{Fe}(\mathrm{II})$ precipitation vs. reductive Fe(III) dissolution. Charette and Sholkovitz (2006) reported U concentration in Waquoit subterranean estuary (Table 2) and observed a strongly nonconservative behavior of $U$ with an overall net $U$ removal over the entire salinity range. They also reported evidence for $U$ increase above seawater values at the high salinity end which likely reflect the release of adsorbed U(IV) under more oxidizing conditions. As presented in Figure 7A, low $\delta^{56} \mathrm{Fe}$ values correlate well with high concentration of $U$ in porewater. Assuming that significant oxidation of porewater Fe(II) and precipitation of Fe-oxyhydroxide are associated with 
U-rich pore waters, the low $\delta^{56} \mathrm{Fe}$ values (down to $-5 \%$ ) in the sediment cores can result from the precipitation of isotopically heavy Fe-oxyhydroxides rather than from the reductive dissolution of Fe-oxyhydroxides.

As illustrated in Figure 7B, the oxidative Fe precipitation can explain the observed range of $\mathrm{Fe}(\mathrm{II})$ concentrations (from $500 \mu \mathrm{M}$ to $25 \mu \mathrm{M}$ ), as well as the Fe-isotopic composition in porewater. The simple model presented in Figure 7B assumes Rayleigh-type Fe-isotope fractionation in porewater during oxidative Fe precipitation. Considering an initial porewater Fe concentration of $500 \mu \mathrm{M}$ and $\delta^{56} \mathrm{Fe}$ value of $-0.5 \%$, $\delta^{56} \mathrm{Fe}$ values as low as $-5 \%$ would be expected after $95 \%$ of Fe-precipitation as Fe-oxyhydroxides with a fractionation factor of 1.0015 (Balci et al., 2006). Similar low $\delta^{56} \mathrm{Fe}$ values may be also obtained with smaller fractionation factors $\sim 1.0012$ as those suggested during Fe(II) oxidation and precipitation of Fe-oxyhydroxides in sediment cores, but requires lower initial $\delta^{56} \mathrm{Fe}$ values at around $-1.5 \%$ (Figure 7B). Additional fractionation is thus required if a significant fraction of precipitated Fe-oxides are further reduced and returned to the Fe(II) pool. For example, field observations suggest that redox gradients in Waquoit Bay groundwater are tightly coupled to seasonal and interannual movement of the fresh-saline groundwater interface (Charette et al., 2007).

Thus, multiple cycles of Fe-reduction and oxidation are likely to occur within the subterranean estuary at Waquoit Bay and can produce $\delta^{56} \mathrm{Fe}$ values down to $-5 \%$ in the porewaters. However, it is important to note that, though Fe reduction is responsible for the enrichment of $\mathrm{Fe}$ in porewater, strongly negative values of Fe-isotopes are mostly the result of the oxidative pathways of the Fe cycle and the sequestration of heavy Fe-isotopes in Fe-oxides. It is also possible that $\mathrm{Fe}$ (II) could be adsorbed onto newly formed Fe-oxyhydroxides in sediment during increasing oxygenation. Teutch et al. (2005) reported strong Fe-isotope fractionation (up to $3 \%$ ) in groundwater $\mathrm{Fe}(\mathrm{II})$ resulting from rapid adsorption of $\mathrm{Fe}(\mathrm{II})$ on Fe-oxyhydroxides formed during injection of $\mathrm{O}_{2}$-containing water. Similar process may also be important in the subterranean estuary at Waquoit Bay given the high Fe-oxyhydroxide content in cores.

Fe-isotope results in the subterranean estuary of Waquoit Bay could be also compared to recent studies of Fe-isotope composition in Fe-oxide concretion from the Navajo Sandstone that precipitated from reducing Fe-rich groundwater (Chan et al., 2006; Busigny and Dauphas, 2007). In these studies, negative $\delta^{56} \mathrm{Fe}$ values for Fe-oxide concretions (down to $\sim-2 \%$ ) have been 
explained by complete oxidation and precipitation from aqueous fluids that had negative $\delta^{56} \mathrm{Fe}$ values. These low $\delta^{56} \mathrm{Fe}$ values have been either interpreted as resulting from bacterial reduction of Fe-oxides (Chan et al., 2006) or evolution of the fluid composition through precipitation and/or adsorption isotopically heavy Fe during fluid flow (Busigny and Dauphas, 2007). These studies can be reconciled if both bacterial reduction of Fe-oxides and partial $\mathrm{Fe}(\mathrm{II})$ oxidation occur in conjunction in $\mathrm{O}_{2}$-depleted environments, as those observed at Waquoit Bay.

\subsection{Hydrogeochemical Model}

The conceptual model of Fe-isotope systematic in subterranean estuary at Waquoit Bay is presented in the schematic diagram in Figure 8. This figure incorporates the hydrology of the subterranean estuary as described previously (Charette et al., 2005; Charette and Sholkovitz, 2006) as well as Fe-isotope compositions observed in this study. Seepage meter studies at Waquoit Bay have shown that subterranean circulation leads to the upward flow of saline pore water to the intertidal zone (Michael et al., 2003; Sholkovitz et al., 2003). A plume of seaward flowing fresh groundwater and recirculating seawater lead to a salt-wedge type distribution of pore-water salinity. The sedimentary and aqueous environment of this subterranean estuary is one of active redox reactions for $\mathrm{Fe}$ where two major sources and oxidative sinks of reduced iron are found: (1) a freshwater plume from the land transporting high concentrations of dissolved $\mathrm{Fe}(\mathrm{II})$ toward the bay where the precipitation of iron oxyhydroxides occurs in the freshwater end of the plume (resulting from oxic seawater recirculation and/or $\mathrm{pH}$ increase); and (2) the upward transport and oxidation of $\mathrm{Fe}(\mathrm{II})$-rich pore waters in the saline zone (representing the major source of the iron oxyhydroxide rich cores reported in this study). These terrestrial and marine sources are probably interconnected as they operate within several meters of each other in the vertical and offshore directions. Since both end-members have $\delta^{56} \mathrm{Fe}$ values varying between 0.3 and $-1.3 \%$, likely resulting from dissimilatory Fe reduction (noted as DIR in Fig. 8), most of the Fe-isotope fractionation is occurring during oxidative precipitation of Fe-oxyhydroxide (noted as OIP in Fig. 8) within the mixing zone between groundwater and brackish $\mathrm{O}_{2}$-depleted porewater. Hence, both high concentration of $\mathrm{Fe}(\mathrm{II})$ in porewater (resulting from DIR) and partial $\mathrm{Fe}$ (II) oxidation are required to produce the large scale Fe-isotope fractionation found in both sediment and porewater. 
It is likely that this large-scale Fe isotope fractionation (up to 5\%o) produced by the precipitation of Fe-oxides in permeable sediments during the mixing of anoxic groundwater with seawater is not restricted to the subterranean estuary at Waquoit Bay. More generally, any coastal aquifer with pore water bearing high dissolved ferrous iron that intercepts oxic to suboxic seawater may produce a $\mathrm{Fe}(\mathrm{II})$ flux to coastal seawater characterized by negative $\delta^{56} \mathrm{Fe}$ values. The radium isotope studies by Charette et al. (2001) show that there is strong groundwater signature in Waquoit Bay water. Although the isotopic composition of dissolved and suspended Fe in the water column of Waquoit Bay has yet to be measured, our results imply that subterranean estuary may impact Fe-isotope budget in coastal waters.

\section{Conclusions}

Dissolved Fe has a distinctly non-conservative behavior in estuaries (Sholkovitz, 1976; Boyle et al., 1977; Mayer, 1982) due to the rapid flocculation of dissolved Fe and humic substances during mixing between rivers and seawater. Similar features are also observed in subterranean estuaries but here, redox characteristics of the freshwater and seawater have significant influence on the partitioning of Fe between the solid and aqueous phases. In previous studies, it has been demonstrated that the upward transport of Fe(II)-rich groundwater is responsible for the formation of Fe oxide-rich sands (Iron Curtain) in the subterranean estuary of Waquoit Bay (Charette and Sholkovitz, 2002). In this study, we reported a large scale Fe isotope fractionation in iron-coated sands and porewater in the intertidal zone of Waquoit Bay. The distribution of $\mathrm{Fe}$-isotopes in pore water reveal that very low $\delta^{56} \mathrm{Fe}$ values of porewater down to 5\% occur within the mixing zone of the subterranean estuary. We interpret the Fe-isotope fractionation to reflect intensive Fe-redox cycling across a density interface between anoxic groundwater and $\mathrm{O}_{2}$-deficient saline porewaters. Large range of $\delta^{56} \mathrm{Fe}$ values, between -2 and 1.5\% has been also observed in two sediment cores across the subterranean estuary. The relationship between $\mathrm{Fe}$ concentration and $\delta^{56} \mathrm{Fe}$ values of $\mathrm{Fe}$ oxides can be modeled by incremental processes (distillation) during the progressive precipitation of Fe-oxides during fluid flow across the subterranean estuary. These results suggest that partial $\mathrm{Fe}(\mathrm{II})$ oxidation in low $\mathrm{O}_{2}$ conditions is the major process producing the large scale Fe-isotope fractionation found in both sediment and porewater. 
The Fe isotope composition of dissolved $\mathrm{Fe}$ in oceanic water masses has not been systematically determined as the analytical difficulties have yet to be mastered. Hydrogenous accumulations in the form of ferromanganese (Fe-Mn) oxides display variable, but negative $\delta^{56} \mathrm{Fe}$ values that may provide record of marine Fe isotope composition (Zhu et al., 2000; Levasseur et al., 2004). Among potential sources of negative $\delta^{56} \mathrm{Fe}$ components in seawater, continental runoff (Fantle and Depaolo, 2004), hydrothermal sources (Beard et al., 2003b) and diagenetic pore fluids from shelf sediments (Staubwasser et al., 2005; Severmann et al., 2006) have been suggested to provide significant source of low- $\delta^{56} \mathrm{Fe}$ iron to the oceans. In this study, we demonstrated that groundwater input in subterranean estuaries may also represent a significant source of light $\mathrm{Fe}$ in seawater due to the preferential sequestration of heavy Fe-isotopes in sediments, yielding aqueous $\mathrm{Fe}(\mathrm{II})$ with $\delta^{56} \mathrm{Fe}$ down to $-5.0 \%$. Considering the recently recognized importance of submarine groundwater input as source of dissolve Fe in the ocean (Windom et al., 2006), future studies will need to focus on the Fe isotopic composition of coastal waters in order to further our understanding of the links between biogeochemical processes occurring in subterranean estuaries and coastal water Fe pools. 


\section{Acknowledgments}

This study was supported by the National Science Foundation (OCE 0550066) to OR and ES , (OCE 0095384) to MC and ES and NASA Astrobiology Institute - Cycle 3 CAN-02-OSS-02 to KJE. Lary Ball is thanked for his technical support on the Neptune MC-ICPMS at WHOI. We

thank Silke Severmann, Derek Vance, Tim Lyons and two anonymous reviewers for helpful comments on the manuscript. 


\section{Appendix A}

The model runs as follows. First, pore water $\mathrm{Fe}^{2+}$ concentrations within the uppermost $2 \mathrm{~m}$ of the sediments are determined using the general 1-dimension diagenetic model described by Richter and De Paolo (1987) and Berner (1980):

$$
\frac{\partial C i}{\partial t}=D c \frac{\partial^{2} C i}{\partial z^{2}}-v \frac{\partial C i}{\partial z}+\sum R
$$

where $\mathrm{Ci}$ represents the concentration of the solute $i, \mathrm{t}$ is the time, $\mathrm{z}$ is the depth, Dc is the diffusivity of the solute $i, v$ is the advective velocity and $\Sigma R$ represents the sum of the reaction terms.

In the case of homogeneous $\mathrm{Fe}(\mathrm{II})$-oxidation in porewater, $\Sigma \mathrm{R}$ is given by

$$
\sum R=-k 1[\mathrm{Fe}(I I)]
$$

where $\mathrm{k} 1$ is the pseudo-first-order rate constant of $\mathrm{Fe}(\mathrm{II})$ oxidation which is strongly dependent upon $\mathrm{pH}$ and $\mathrm{O}_{2}$ (e.g. Millero et al., 1987) following:

$$
\mathrm{k} 1=-\mathrm{k}\left[\mathrm{OH}^{-}\right]\left[\mathrm{O}_{2}\right]
$$

To a first approximation, this formulation does not take into account the heterogeneous oxidation whereby the rate of oxidation increases with the concentration of Fe(III) hydroxide due to autocatalytic effects.

The diffusion coefficient Dc is related to the temperature, porosity and tortuosity of the sediment which are considered constant with depth over the uppermost 2-m of sediment section. Given a porosity of 0.35 for sand sediments at Waquoit Bay (Hoefel and Evans, 2001), $\mathrm{D}_{\mathrm{Fe} 2+}$ can be estimated at $\sim 0.04 \mathrm{~cm}^{2} \mathrm{~d}^{-1}$ ( $\mathrm{Li}$ and Gregory, 1974). The groundwater discharge for the head of Waquoit Bay has been estimated by Abraham et al. (2003) at $v \sim 8 \mathrm{~cm} \mathrm{~d}^{-1}$. Although the total groundwater discharge proceeds through both horizontal and vertical transport, we only considered vertical advection in our model. Because only two cores have been investigated in this study, it is presently impossible to develop a more complex 2D advection-reaction model.

This suggests that $\mathrm{Fe}^{2+}$ transport through the sediments is essentially advective (i.e. Peclet number $>>1$ ) and that equation (a.1) could be simplified as:

$$
\frac{\partial F e^{2+}}{\partial t}=-v \frac{\partial F e^{2+}}{\partial z}-k 1\left[F e^{2+}\right]
$$


Since Fe(II) oxidation fractionate Fe-isotopes toward heavy isotopes in the insoluble $\mathrm{Fe}(\mathrm{III})$ product, the rate of $\mathrm{Fe}(\mathrm{II})$ oxidation is different between Fe-isotopes and equation (a.4) can be written for ${ }^{56} \mathrm{Fe}$ and ${ }^{54} \mathrm{Fe}$ isotopes:

$$
\begin{aligned}
& \frac{\partial^{56} \mathrm{Fe}^{2+}}{\partial t}=-v \frac{\partial^{56} \mathrm{Fe} e^{2+}}{\partial z}-{ }^{56} k 1\left[{ }^{56} \mathrm{Fe}^{2+}\right] \\
& \frac{\partial^{54} \mathrm{Fe} e^{2+}}{\partial t}=-v \frac{\partial^{54} \mathrm{Fe} e^{2+}}{\partial z}-{ }^{54} k 1\left[{ }^{54} \mathrm{Fe}^{2+}\right]
\end{aligned}
$$

Where ${ }^{54} \mathrm{k} 1$ and ${ }^{56} \mathrm{k} 1$ are the pseudo-first-order rate constant of ${ }^{54} \mathrm{Fe}(\mathrm{II})$ and ${ }^{56} \mathrm{Fe}(\mathrm{II})$ oxidation respectively. It is also assumed no differences in advection rate $v$ between ${ }^{54} \mathrm{Fe}$ and ${ }^{56} \mathrm{Fe}$ isotopes.

The isotope fractionation factor during Fe(II) oxidation $\alpha$ which is generally determined between 1.001 and 1.0015 (Bullen et al., 2001; Croal et al., 2004; Balci et al., 2006) is defined by

$$
\alpha={ }^{56} k 1 / 54 k 1
$$

The theoretical relationship between $\mathrm{Fe}^{2+}$ concentration and isotope composition in porewater can be calculated using the DuFort-Frankel scheme, an explicit three-level finite difference method (Dufort and Frankel, 1953; Richter and De Paolo, 1987). This model is stepped in time and space allowing for advection and reaction. $\mathrm{Fe}^{2+}$ concentration and ${ }^{56} \mathrm{Fe} /{ }^{54} \mathrm{Fe}$ isotope ratios are calculated for each depth intervals using equations (4) and (5). The evolution of $\mathrm{Fe}^{2+}{ }_{\mathrm{t}, \mathrm{z}}$ at time $t$ and depth $\mathrm{z}$ is described by

$$
\frac{F e^{2+}{ }_{t+1, z}-F e^{2+}{ }_{t-1, z}}{2 \Delta t}=-v \frac{F e^{2+}{ }_{t, z+1}-F e^{2+}{ }_{t, z-1}}{2 \Delta z}-k 1\left[F e^{2+}{ }_{t-1, z}\right]
$$

The parameter $\Delta \mathrm{t}$ is the time step used in the model calculation (in day) while $\Delta \mathrm{z}$ is the grid spacing in cm. Similarly, ${ }^{54} \mathrm{Fe}^{2+}{ }_{\mathrm{t}, \mathrm{z}}$ and ${ }^{56} \mathrm{Fe}^{2+}{ }_{\mathrm{t}, \mathrm{z}}$ are calculated using the same centered finite approach for solving equations (a.5) and (a.6).

Since Fe-oxidation product is insoluble and considered immobile in sediments, $\mathrm{Fe}$ (III) concentration can be calculated for each depth intervals, such as:

$$
\frac{\partial F e(I I I)}{\partial t}=k 1\left[F e^{2+}\right] \frac{\Phi}{\rho(1-\Phi)}
$$


Where $\rho$ is sediment density $\left(\sim 2 \mathrm{~g} \mathrm{~cm}^{-3}\right)$ and $\Phi$ sediment porosity of $\sim 0.35$ for sediments at Waquoit Bay.

The evolution of ${ }^{54} \mathrm{Fe}(\mathrm{III})$ and ${ }^{56} \mathrm{Fe}(\mathrm{III})$ at time $\mathrm{t}$ and depth $\mathrm{z}$ is then described by:

$$
\begin{aligned}
& \frac{{ }^{56} \mathrm{Fe}(I I I)_{t+1, z}-{ }^{56} \mathrm{Fe}(I I I)_{t-1, z}}{2 \Delta t}=k 1 \frac{\Phi}{\rho(1-\Phi)}\left[{ }^{56} \mathrm{Fe}^{2+}{ }_{t-1, z}\right] \\
& \frac{{ }^{54} \mathrm{Fe}(I I I)_{t+1, z}-{ }^{54} \mathrm{Fe}(I I I)_{t-1, z}}{2 \Delta t}=\frac{k 1}{\alpha} \frac{\Phi}{\rho(1-\Phi)}\left[{ }^{54} \mathrm{Fe}^{2+}{ }_{t-1, z}\right]
\end{aligned}
$$

Where we solve ${ }^{54} \mathrm{Fe}(\mathrm{III})_{\mathrm{t}+1, \mathrm{z}}$ and ${ }^{56} \mathrm{Fe}(\mathrm{III})_{\mathrm{t}+1, \mathrm{z}}$ and allow the determination of $\delta^{56} \mathrm{Fe}$ values of $\mathrm{Fe}-$ oxides at any depth z. The model is run until Fe(III) concentrations reaches the present day. Only parameters $\mathrm{k} 1$ (rate of $\mathrm{Fe}^{2+}$ oxidation) and fractionation factor $\alpha$ are adjusted to give a best fit of $\mathrm{Fe}(\mathrm{III})$ vs. $\delta^{56} \mathrm{Fe}$ relationship. 


\section{Figure Captions}

Figure 1 : Location of Waquoit Bay on Cape Cod, USA. The Bay opens to open seawater at the southern end. The expanded map of the head of the Bay shows the location of the piezometers along a profile (A-A') perpendicular to the shoreline. Location for piezometer \#4 Core\#2 and Core\#3 are also presented.

Figure 2 : Cross section of pore water salinity and total dissolve Fe concentration (T.D. Fe) in $\mu \mathrm{M}$ along the shore-perpendicular transect A-A' in Fig.1. The isochores of constant salinity and and T.D. Fe and the corresponding Piezometer measurements from this study is shown in each box. The piezometer station numbers for each profile are located along the top edge of the figure. Locations of samples selected for Fe-isotope analysis are marked with «*». Results for Piezometer\#4 are not presented. Location and depth of Core \#2 along the transect A-A' is also presented for comparison. Modified after Charette and Sholkovitz (2006).

Figure 3: Downhole variations of Fe-concentration and Fe-isotope composition in Feoxyhydroxide coated sands from A) Core\#2 and B) Core\#3. Core 2 and Core 3 are located in the tidal zone of the head of Waquoit Bay near piezometer \#8 and \#4 respectively (see Fig.1). Gray shaded area correspond to the range of Fe-concentration and Fe-isotope composition for "offsite" surface beach sands reported in Table 1.

Figure 4: Relationship between Fe-concentration and Fe-isotope composition of Feoxyhydroxide coated sands in Core 2 and 3. Simple mixing relationships between Feoxyhydroxide coated sands at the bottom of Core 2 and 3 and surface beach sands $([\mathrm{Fe}]=500$ ppm $\delta^{56} \mathrm{Fe}=0 \%$ ) are illustrated using dashed lines. Gray and black lines correspond to the theoretical relationships between Fe concentration and Fe-isotope composition of sediments for each depth and are calculated using advection-reaction model during partial Fe(II) oxidation and Fe-oxyhydroxide precipitation. A) Model line for Core 2 is calculated using initial conditions for $\delta^{56} \mathrm{Fe}=0.8 \%$, $\mathrm{Fe}(\mathrm{II})$ oxidation rate of $0.12 \mathrm{~d}^{-1}$ and isotope fractionation factor $\alpha=1.001$. B) Both model lines for Core 3 are calculated using initial conditions for $\delta^{56} \mathrm{Fe}=-0.8 \%$ and isotope 
fractionation factor $\alpha=1.0012$. Gray line and black lines are calculated using Fe(II) oxidation rate of $0.25 \mathrm{~d}^{-1}$ and $0.4 \mathrm{~d}^{-1}$ respectively. See text and Appendix for discussion.

Figure 5: Conceptual model used for calculating theoretical relationship between Feconcentration and Fe-isotope composition observed in Fe-oxyhydroxide coated sands in Core 2 and 3. In this model, the upward transport and oxidation of $\mathrm{Fe}(\mathrm{II})$-rich pore waters from saline zone and/or freshwater represents the major source of the Fe-oxyhydroxide rich cores. In addition, it is assumed that sands contain significant proportion of « background » Fe-oxides with $\delta^{56} \mathrm{Fe}$ near $0 \%$ as demonstrated by the analysis of surface sands in area not affected by groundwater input (Table 1). During Oxidative Fe Precipitation (OIP), newly formed Feoxyhydroxide will preferentially incorporate heavy Fe-isotopes, producing a remaining aqueous $\mathrm{Fe}(\mathrm{II})$ pool enriched in light Fe-isotopes.

Figure 6: Relationships between Fe-concentration and Fe-isotope composition relative to porewater salinity. Porewater along the transect A-A' (and specially related) are presented with the same symbol whereas porewater from piezometer $4(50 \mathrm{~m}$ along shore $)$ is presented separately. The source of dissolved Fe in high-salinity pore water concentrations (up to $500 \mu \mathrm{M}$ ) results from chemical diagenesis typical of that found in reducing marine sediments where microbial activity leads to the reduction of $\mathrm{Fe}$ oxide. Shaded area represents the range of Feconcentration and isotope composition in freshwater source for Fe in the subterranean estuary.

Figure 7: A) and B) comparison of Fe-concentrations, Fe-isotope compositions and $U$ concentrations in porewaters for different salinity. DIR = Dissimilatory Iron Reduction; OIP = Oxidative Iron Precipitation. A) U concentrations fir local coastal seawater near Waquoit Bay are shown in comparison (data from Charette and Sholkovitz, 2006) and suggest that U, in most case, is removed under low $\mathrm{O}_{2}$ conditions in Waquoit Bay subterranean estuary. B) Example of $\delta^{56} \mathrm{Fe}$ vs. [Fe] relationships for DIR and OIP are shown for comparison. Initial reduction of ferric oxide substrate (i.e. open system reduction) produce $\delta^{56} \mathrm{Fe}$ values for $\mathrm{Fe}(\mathrm{II})$ down to $-1.3 \%$ and converge to initial Fe-isotope composition at high rate of DIR (i.e. close system reduction). OIP following Rayleigh-type distillation process is also presented. In this case, only large extent of 
Fe-oxidation will produce large Fe-isotope fractionation (down to -5\%) in remaining aqueous $\mathrm{Fe}(\mathrm{II})$ pool.

Figure 8 : Conceptual hydrogeochemical model at Waquoit Bay across a section perpendicular to transect A-A' in Fig.1. This model integrates porewater Fe concentrations profile presented in Figure 2 with high Fe(II) concentration represented as light-gray domain. Fe-oxide-rich sands (referred as “iron curtain') are represented as dark gray area. Oxidative Fe precipitation (OIP) and dissimilatory Fe reduction (DIR) processes are also presented to illustrate possible pathways of Fe-reduction and oxidation between different Fe reservoirs. 


\section{References}

Abraham, D. R., Charette, M. A., Allen, M. C., Rago, A., and Kroeger, K. D., 2003. Radiochemical estimates of submarine groundwater discharge to Waquoit Bay, Massachusetts. Bio. Bull. 205, 246-247.

Anbar, A. D., Jarzecki, A. A., and Spiro, T. G., 2005. Theoretical investigation of iron isotope fractionation between $\mathrm{Fe}(\mathrm{H} 2 \mathrm{O})_{6}{ }^{3+}$ and $\mathrm{Fe}(\mathrm{H} 2 \mathrm{O})_{6}{ }^{2+}$ : Implications for iron stable isotope geochemistry. Geochim. Cosmochim. Acta 69, 825-837.

Anbar, A. D. and Rouxel, O., 2007. Metal Stable Isotopes in Paleoceanography. Annu. Rev. Earth Planet. Sci 35, 717-746.

Archer, D. E. and Johnson, K., 2000. A model of the iron cycle in the ocean. Global Biogeochemical Cycles 14, 269-279.

Arnold, G. L., Weyer, S., and Anbar, A. D., 2004. Fe Isotope variations in natural materials measured using high mass resolution multiple collector ICPMS. Anal. Chem. 76, 322-327.

Balci, N., Bullen, T. D., Witte-Lien, K., Shanks, W. C., Motelica, M., and Mandernack, K. W., 2006. Iron isotope fractionation during microbially stimulated $\mathrm{Fe}$ (II) oxidation and $\mathrm{Fe}(\mathrm{III})$ precipitation. Geochim. Cosmochim. Acta 70, 622-639.

Barnes, C. E. and Cochran, J. K., 1990. Uranium removal in oceanic sediments and the oceanic U balance. Earth Planet. Sci. Lett. 97, 94-101.

Beard, B. L., Johnson, C. M., Cox, L., sun, H., Nealson, K. H., and Aguilar, C., 1999. Iron Isotope Biosignatures. Science 285, 1889-1892.

Beard, B. L., Johnson, C. M., Skulan, J. L., Nealson, K. H., Cox, L., and Sun, H., 2003 a. Application of $\mathrm{Fe}$ isotopes to tracing the geochemical and biological cycling of $\mathrm{Fe}$. Chemical Geology 195, 87-117.

Beard, B. L., Johnson, C. M., VonDamm, K. L., and Poulson, R. L., 2003b. Iron isotope constraints on Fe cycling and mass balance in oxygenated Earth oceans. Geology 31, 629632.

Belshaw, N. S., Zhu, X. K., Guo, Y., and O'Nions, R. K., 2000. High precision measurement of iron isotopes by plasma source mass spectrometry. International Journal of Mass Spectrometry and Ion Processes 197, 191-195.

Bergquist, B. and Boyle, E., 2006. Iron isotopes in the Amazon river system: weathering and transport signatures. Earth Planet. Sci. Lett. 248, 54-68.

Berner, R. A., 1980. Early Diagenesis: A Theoretical Approach. Princeton University Press, Princeton, NJ.

Boyd, P. W., Watson, A. J., Law, C. S., Abraham, E. R., Trull, T., R.Murdoch, Bakker, D. C. E., Bowie, A., Buesseler, K. O., Chang, H., Charette, M., Croot, P., Downing, K., Frew, R., Gall, M., Hadfield, M., Hall, J., Harvey, M., Jameson, G., DeLaRoche, J., Liddicoat, M., Ling, R., Maldonado, M. T., McKay, R. M., Nodder, S., Pickmere, S., Pridmore, R., Rintoul, S., Safi, K., Sutton, P., Strzepek, R., Tanneberger, K., Turner, S., Waite, A., and Zeldis, J., 2000. A mesoscale phytoplankton bloom in the polar Southern Ocean stimulated by iron fertilization. Nature 407, 695-702.

Boyle, E. A., Bergquist, B. B., Kayser, R., and Mahowald, N., 2005. Iron, manganese, and lead at Hawaii Ocean Time-series Station ALOHA: Temporal Variability and an Intermediate Water Hydrothermal Plume. Geochim. Cosmochim. Acta 69, 933-952.

Boyle, E. A., Edmond, J. M., and Sholkovitz, E. R., 1977. The mechanism of iron removal in estuaries. Geochim. Cosmochim. Acta 41, 1313-1324. 
Brantley, B. L., Liermann, L. J., Guynn, R. L., Anbar, A., Icopini, G. A., and Barling, J., 2004. Fe isotopic fractionation during mineral dissolution with and without bacteria. Geochim. Cosmochim. Acta 68, 3189-3204.

Brantley, S. L., Liermann, L., and Bullen, T. D., 2001. Fractionation of Fe isotopes by soil microbes and organic acids. Geology 29, 535-538.

Buck, K. N., Lohan, M. C., Berger, C. J. M., and Bruland, K. W., 2007. Dissolved iron speciation in two distinct river plumes and an estuary: Implications for riverine iron supply. Limnol. Oceanogr. 52, 843-855.

Bullen, T. D., White, A. F., Childs, C. W., Vivit, D. V., and Schulz, M. S., 2001. Demonstration of significant abiotic iron isotope fractionation in nature. Geology 29, 699-702.

Busigny, V. and Dauphas, N., 2007. Tracing paleofluid circulations using iron isotopes: A study of hematite and goethite concretions from the Navajo Sandstone (Utah, USA). Earth. Planet. Sci. Lett. 254, 272-287.

Chaillou, G., Anschutz, P., Lavaux, G., Schafer, J., and Blanc, G., 2002. The distribution of Mo, $\mathrm{U}$, and $\mathrm{Cd}$ in relation to major redox species in muddy sediments of the Bay of Biscay. Marine Chemistry 80, 41- 59.

Chan, M. A., Johnson, C. M., Beard, B. L., Bowman, J. R., and Parry, W. T., 2006. Iron isotopes constrain the pathways and formation mechanisms of terrestrial oxide concretions: A tool for tracing iron cycling on Mars. Geosphere 2, 324-332.

Charette, M. A. and Allen, M. C., 2006. Precision Ground Water Sampling in Coastal Aquifers Using a Direct-Push, Shielded-Screen Well-Point System. Ground Water Monitoring \& Remediation 26(2), 87-93.

Charette, M. A., Buesseler, K. O., and Andrews, J. E., 2001. Utility of radium isotopes for evaluating the input and transport of groundwater-derived nitrogen to a Cape Cod estuary. Limnol. Oceanogr. 46, 465-470.

Charette, M. A. and Sholkovitz, E. R., 2002. Oxidative precipitation of groundwater-derived ferrous iron in the subterranean estuary of a coastal bay. Geophysical Research Letters 29, doi:10.1029/2001GL014512.

Charette, M. A. and Sholkovitz, E. R., 2006. Trace element in a subterranean estuary: Part 2. Geochemistry of pore water. Geochim. Cosmochim. Acta 70, 811-826.

Charette, M. A., Sholkovitz, E. R., and Hansel, C. M., 2005. Trace element cycling in a subterranean estuary: Part 1. Geochemistry of the permeable sediments. Geochim. Cosmochim. Acta 69, 2095-2109.

Cochran, J. K., Carey, A. E., Sholkovitz, E. R., and Surprenant, L. D., 1986. The geochemistry of uranium and thorium in coastal marine sediments and sediment pore waters. Geochem. Cosmochim. Acta 50, 663-680.

Croal, L. R., Johnson, C. M., Beard, B. L., and Newman, D. K., 2004. Iron isotope fractionation by $\mathrm{Fe}(\mathrm{II})$-oxidizing photoautotrophic bacteria. Geochimica et Cosmochimica Acta 68, 1227-1242.

Crosby, H. A., Roden, E. E., Johnson, C. M., and Beard, B. L., 2007. The mechanisms of iron isotope fractionation produced during dissimilatory Fe(III) reduction by Shewanella putrefaciens and Geobacter sulfurreducens. Geobiology 5, 169-189. 
de Jong, J., Schoemann, V., Tison, J.-L., Becquevort, S., Masson, F., Lannuzel, D., Petit, J., Choua, L., Weis, D., and Mattielli, N., 2007. Precise measurement of Fe isotopes in marine samples by multi-collector inductively coupled plasma mass spectrometry (MCICP-MS). Analytica Chimica Acta 589, 105-119.

DuFort, E. C. and Frankel, S. P., 1953. Stability conditions in the numerical treatment of parabolic differential equations. Mathematical Tables and Other Aids to Computation 7, 135-152.

Elderfield, H. and Schultz, A., 1996. Mid-ocean ridge hydrothermal fluxes and the chemical composition of the ocean. Annu. Rev. Earth Planet. Sci. 24, 191-224.

Elrod, V. A., Berelson, W. M., Coale, K. H., and Johnson, K. S., 2004. The flux of iron from continental shelf sediments: A missing source for global budgets. Gephysical Research Letters 31, doi:10.1029/2004GL020216.

Emmanuel, S., Erel, Y., Matthews, A., and Teutsch, N., 2005. A preliminary mixing model for Fe isotopes in soils. Chemical Geology 222, 23-34.

Escoube, R., Rouxel, O., Sholkovitz, E., and Donard, O., 2007. Iron Isotope Composition of River Water During Estuarine Mixing: Case of North River (Massachusetts, USA). Eos Trans. AGU, 88(52), Fall Meet. Suppl., Abstract H31C-0513.

Fantle, M. S. and DePaolo, D. J., 2004. Iron isotopic fractionation during continental weathering. Earth Planet. Sci. Lett. 228, 547-562.

Froelich, P. N., Klinkhammer, G. P., Bender, M. L., Luedtke, N. A., Heath, G. R., Cullen, D., Dauphin, P., Hammond, D., Hartman, B., and Maynard, V., 1979. Early oxidation of organic matter in pelagic sediments of the eastern equatorial Atlantic: suboxic diagenesis. Geochimica et Cosmochimica Acta 43, 1075-1090.

Hall, G. E. M., Vaive, J. E., Beer, R., and Hoashi, M., 1996. Selective leaches revisited, with emphasis on the amorphous Fe oxyhydroxide phase extraction. J. Geochem. Explor. 56, 59-78.

Hoefel, F. G. and Evans, R. L., 2001. Impact of low salinity porewater on seafloor electromagnetic data: a means of detecting submarine groundwater discharge? Estuarine, Coastal and Shelf Science 52, 179-189.

Hutchins, D. A., Witter, A. E., Butler, A., and LutherIII, G. W., 1999. Competition among marine phytoplankton for different chelated iron species. Nature 400, 858-861.

Icopini, G. A., Anbar, A. D., Ruebush, S. S., Tien, M., and Brantley, S. L., 2004. Iron isotope fractionation during microbial reduction of iron: The importance of adsorption. Geology 32, 205-208.

Jickells, T. D., An, Z. S., Andersen, K. K., Baker, A. R., Bergametti, G., Brooks, N., Cao, J. J., Boyd, P. W., Duce, R. A., Hunter, K. A., Kawahata, H., Kubilay, N., laRoche, J., Liss, P. S., Mahowald, N., Prospero, J. M., Ridgwell, A. J., Tegen, I., and Torres, R., 2005. Global Iron Connections Between Desert Dust, Ocean Biogeochemistry, and Climate. Science 308, 67-71.

Johnson, C. M., Beard, B. L., Roden, E. E., Newman, D. K., and Nealson, K. H., 2004. Isotopic constraints on biological cycling of Fe. Reviews in Mineralogy and Geochemistry 55, 359408.

Johnson, C. M., Skulan, J. L., Beard, B. L., Sun, H., Nealson, K. H., and Braterman, P. S., 2002. Isotopic fractionation between $\mathrm{Fe}(\mathrm{III})$ and $\mathrm{Fe}(\mathrm{II})$ in aqueous solutions. Earth Planet. Sci. Lett. 195, 141-153.

Johnson, K. S., Chavez, F. P., and Friederich, G. E., 1999. Continental-shelf sediment as a primary source of iron for coastal phytoplankton. Nature 398, 697-700. 
Levasseur, S., Frank, M., Hein, J. R., and Halliday, A. N., 2004. The global variation in the iron isotope composition of marine hydrogenetic ferromanganese deposits: implications for seawater chemistry ? Earth and Planetary Science Letters 224, 91-105.

Li, Y.-H. and Gregory, S., 1974. Diffusion of ions in sea water and in deep-sea sediments. Geochem. Cosmochim. Acta 38, 703-714.

Malinovski, D., Stenberg, A., Rodushkin, I., Andren, H., Ingri, J., Ohlander, B., and Baxter, D. C., 2003. Performance of high resolution MC-ICPMS for Fe isotope ratio measurements in sedimentary geological materials. Journal of Analytical Atomic Spectrometry 18, 687695.

Martin, J. H., 1990. Glacial-interglacial CO2 change: the iron hypothesis. Paleoceanography 5, $1-13$.

Mayer, L. M., 1982. Retention of riverine iron in estuaries. Geochim. Cosmochim. Acta 46, 10031009.

McManus, J., Berelson, W. M., Severmann, S., Poulson, R. L., Hammond, D. E., Klinkhammer, G. P., and Holm, C., 2006. Molybdenum and uranium geochemistry in continental margin sediments: Paleoproxy potential. Geochim. Cosmochim. Acta 70, 4643-4662.

Michael, H. A., Lubetsky, J. S., and Harvey, C. F., 2003. Characterizing submarine groundwater discharge: A seepage meter study in Waquoit Bay, Massachusetts. Geophysical Research Letters 30, doi:10.1029/2002GL016000.

Michael, H. A., Mulligan, A. E., and Harvey, C. F., 2005. Seasonal oscillations in water exchange between aquifers and the coastal ocean. Nature 436, 1145-1148.

Millero, F. J., Sotolongo, S., and Izaguirre, M., 1987. The oxidation kinetics of Fe(II) in seawater. Geochimica et Cosmochimica Acta 51, 793-801.

Moore, W. S., 1999. The subterranean estuary: a reaction zone of groundwater and seawater. Marine Chemistry 65, 111-125.

Mulligan, A. E. and Charette, M. A., 2006. Intercomparison of submarine groundwater discharge estimates from a sandy unconfined aquifer. Journal of Hydrology 327, 411-425.

Poitrasson, F. and Freydier, R., 2005. Heavy iron isotope composition of granites determined by high resolution MC-ICP-MS. Chemical Geology 222, 132-147.

Powell, R. T. and Wilson-Finelli, A., 2003. Importance of organic Fe complexing ligands in the Mississippi River plume. Estuarine, Coastal and Shelf Science 58, 757-763.

Richter, F. M. and DePaolo, D. J., 1987. Numerical-models for diagenesis and the Neogene $\mathrm{Sr}$ isotopic evolution of seawater from DSDP Site 590B. Earth Planet. Sci. Lett. 83, 27-38.

Rouxel, O., Bekker, A., and Edwards, K., 2005. Iron Isotope Constraints on the Archean and Paleoproterozoic Ocean Redox State. Science 307, 1088-1091.

Rouxel, O., Dobbek, N., Ludden, J., and Fouquet, Y., 2003. Iron Isotope Fractionation During Oceanic Crust Alteration (Site ODP 801). Chem. Geol. 202, 155-182.

Schoenberg, R. and von Blanckenburg, F., 2005. An assessment of the accuracy of stable Fe isotope ratio measurements of samples with organic and inorganic matrices by highresolution multicollector ICP-MS. Int. J. Mass Spectrom.

Severmann, S., Johnson, C. M., Beard, B. L., and McManus, J., 2006. The effect of early diagenesis on the $\mathrm{Fe}$ isotope compositions of porewaters and authigenic minerals in continental margin sediments. Geochimica et Cosmochimica Acta 70, 2006-2022.

Sholkovitz, E., Herbold, C., and Charette, M., 2003. An automated dye-dilution based seepage meter for the time-series measurement of submarine groundwater discharge. Limnol. Oceanogr. Methods 1, 16-28. 
Sholkovitz, E. R., 1976. Flocculation of dissolved organic and inorganic matter during the mixing of river water and seawater. Geochimica et Cosmochimica Acta 40, 831-845.

Skulan, J. L., Beard, B. L., and Johnson, C. M., 2002. Kinetic and equilibrium Fe isotope fractionation between aqueous Fe(III) and hematite. Geochimica et Cosmochimica Acta 66, 2995-3015.

Slomp, C. P. and VanCappellen, P., 2004. Nutrient inputs to the coastal ocean through submarine groundwater discharge: controls and potential impact. Journal of Hydrology 295, 64-86.

Spiteri, C., Regnier, P., Slomp, C. P., and Charette, M. A., 2006. pH-Dependent iron oxide precipitation in a subterranean estuary. Journal of Geochemical Exploration 88, 399-403.

Staubwasser, M., Schoenberg, R., and vonBlanckenburg, F., 2005. Fe-isotope fractionation during early diagenetic Fe-reduction. Geophysical Research Abstracts, Vol. 7, 09176, 2005.

Teutsch, N., vonGunten, U., Porcelli, D., Cirpka, O. A., and Halliday, A. N., 2005. Adsorption as a cause for Iron Isotope fractionation in reduced groundwater. Geochim. Cosmochim. Acta 17, 4175-4185.

Ussher, S., Worsfold, P. J., Achterberg, E. P., Laës, A., Blain, S., Laan, P., and deBaar, H. J. W., 2007. Distribution and redox speciation of dissolved iron on the European continental margin. Limnol. Oceanogr. 52, 2530-2539.

Welch, S. A., Beard, B. L., Johnson, C. M., and Braterman, P. S., 2003. Kinetic and equilibrium $\mathrm{Fe}$ isotope fractionation between aqueous $\mathrm{Fe}(\mathrm{II})$ and $\mathrm{Fe}(\mathrm{III})$. Geochimica et Cosmochimica Acta 67, 4231-4250.

Wells, M. L., Price, N. M., and Bruland, K. W., 1995. Iron chemistry in seawater and its relationship to phytoplankton: a workshop report. Marine Chemistry 48, 157-182.

Weyer, S. and Schwieters, J. B., 2003. High precision Fe isotope measurements with high mass resolution MC-ICPMS. International Journal of Mass Spectrometry 226, 355-368.

Windom, H. L., Moore, W. S., Niencheski, L. F. H., and Jahnke, R. A., 2006. Submarine groundwater discharge: A large, previously unrecognized source of dissolved iron to the South Atlantic Ocean. Marine Chemistry 102, 252-266.

Wu, J., Boyle, E., Sunda, W., and Wen, L.-S., 2001. Soluble and colloidal iron in the Oligotrophic North Atlantic and North Pacific. Science 293, 847-849.

Zhu, X. K., O'Nions, R. K., Guo, Y., and Reynolds, B. C., 2000. Secular Variation of Iron Isotopes in North Atlantic Deep Water. Science 287, 2000-2002. 


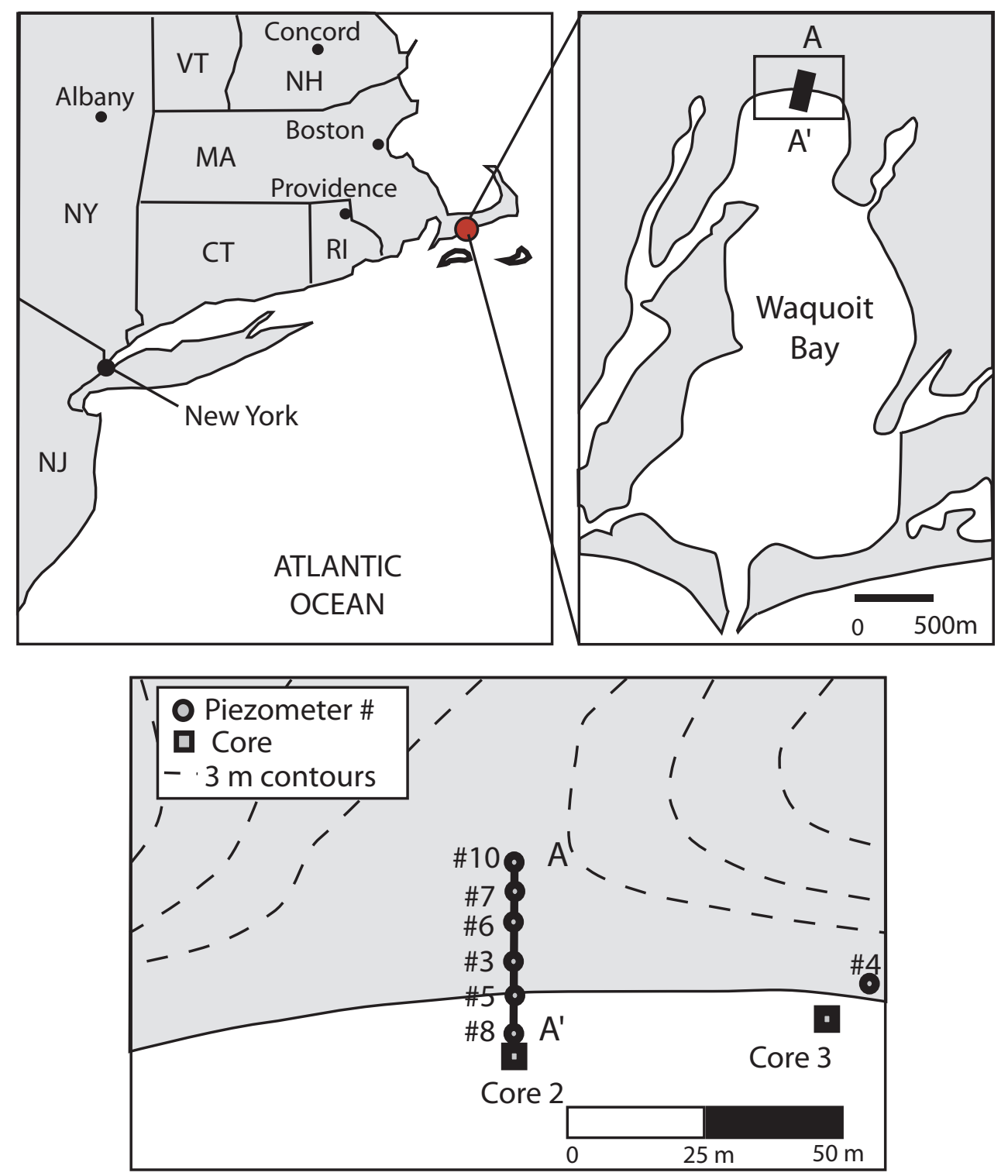

Figure 1 

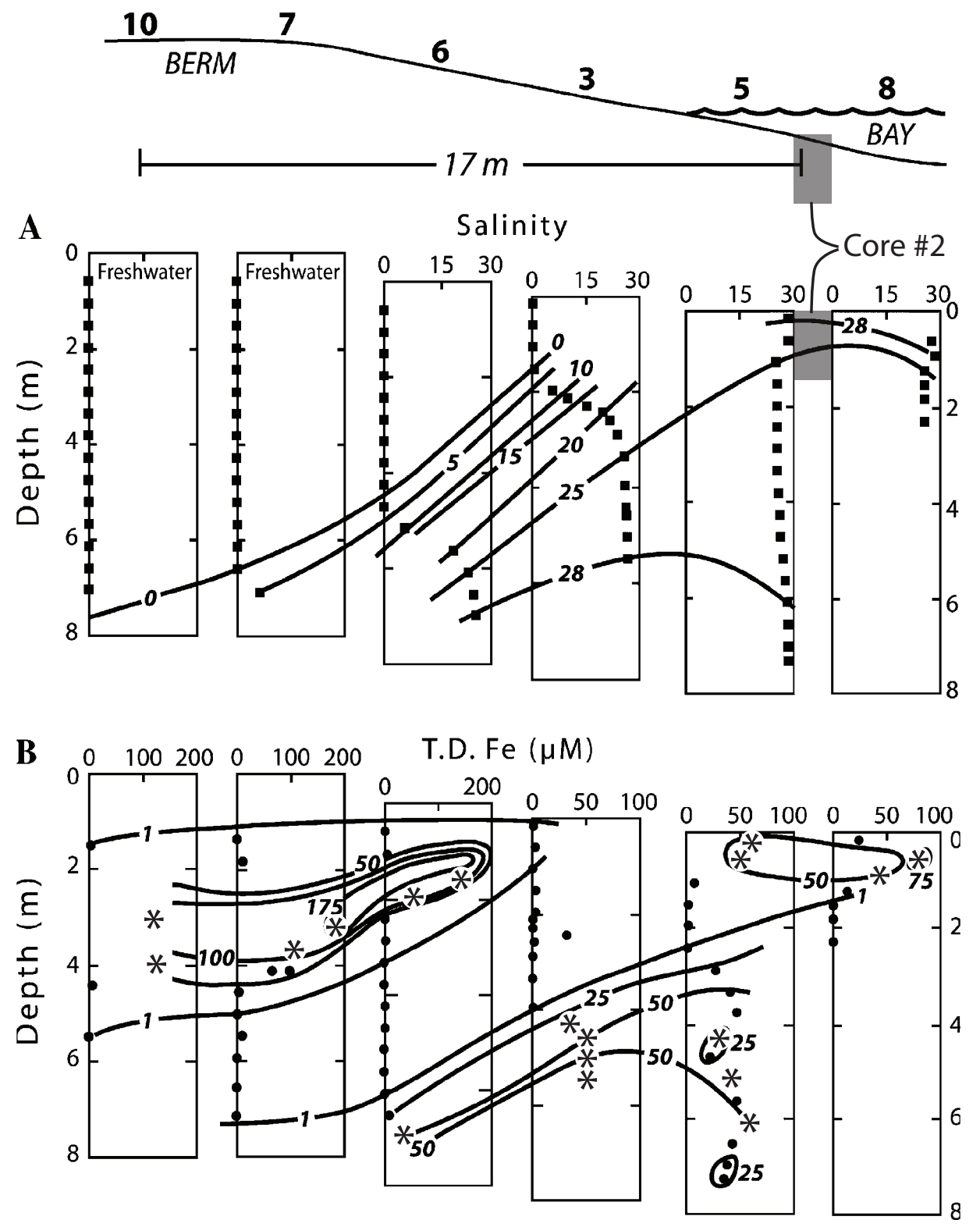

Figure 2 


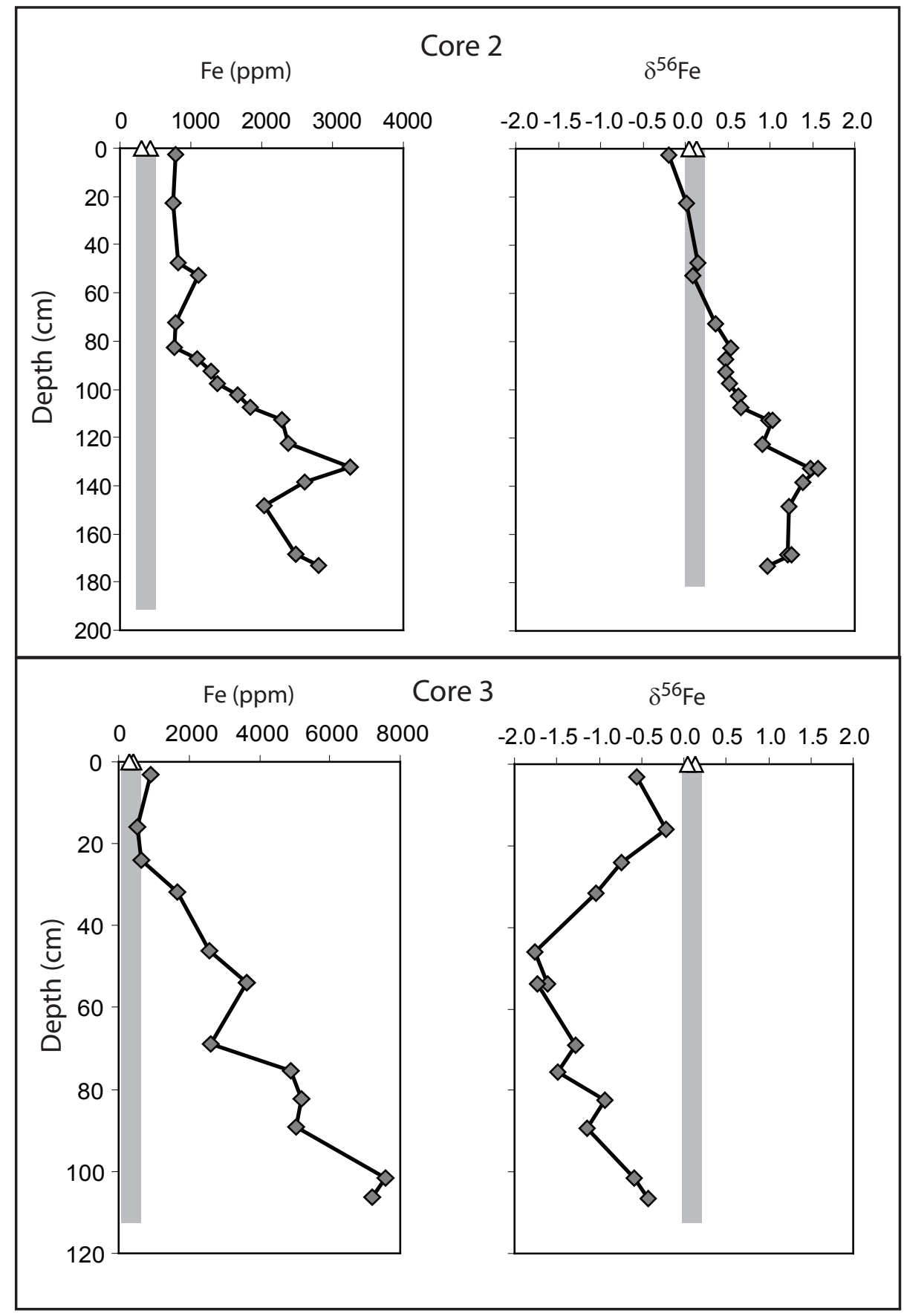

Figure 3 

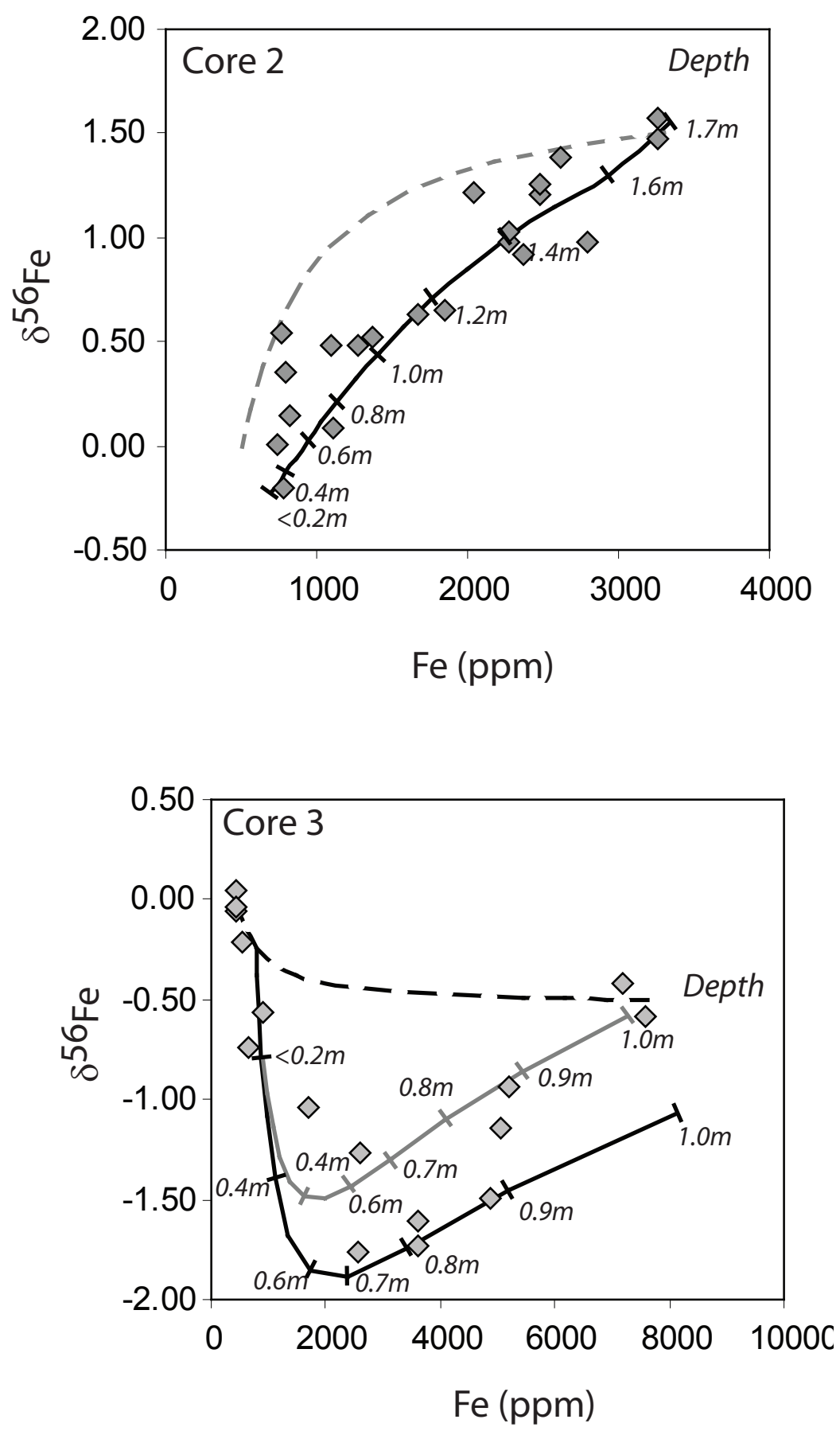

Figure 4 


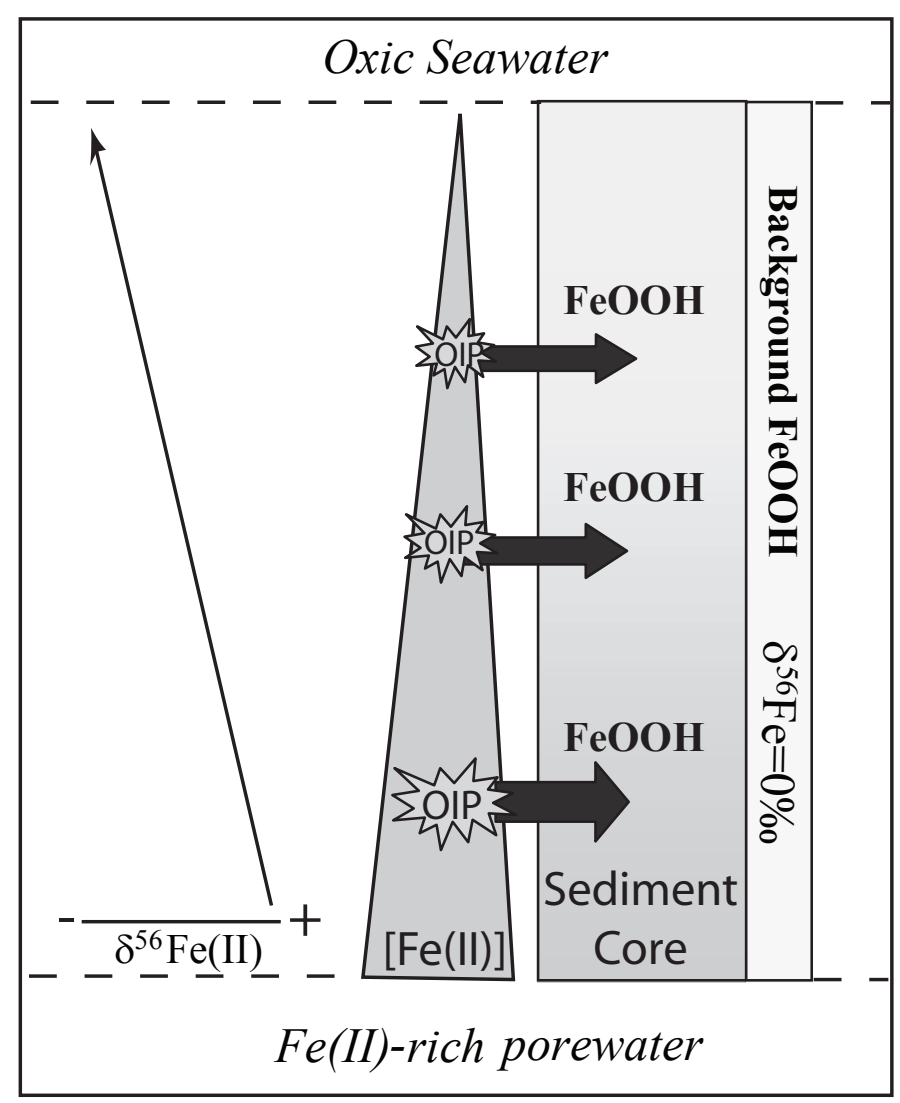

Figure 5 

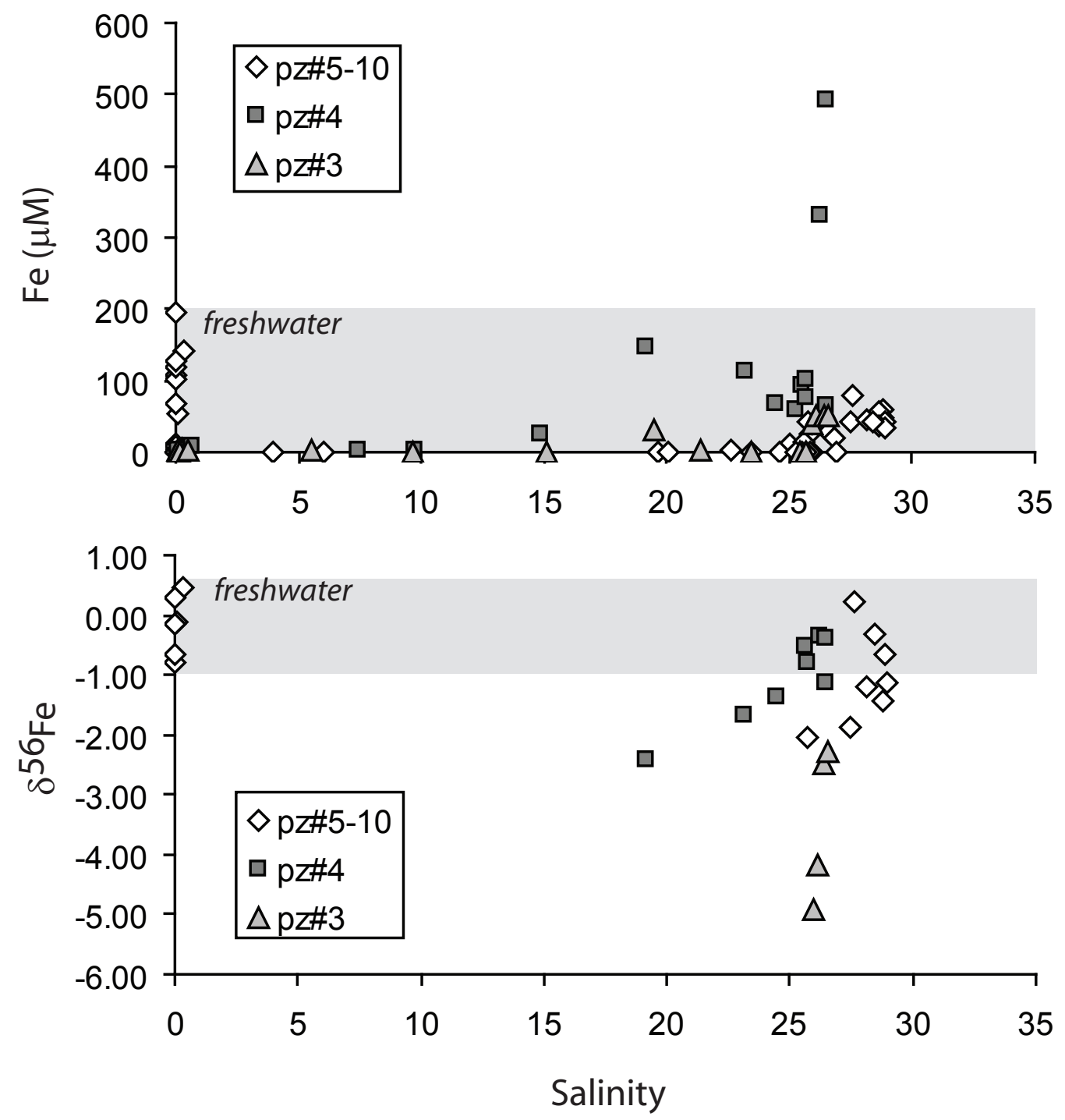

Figure 6 

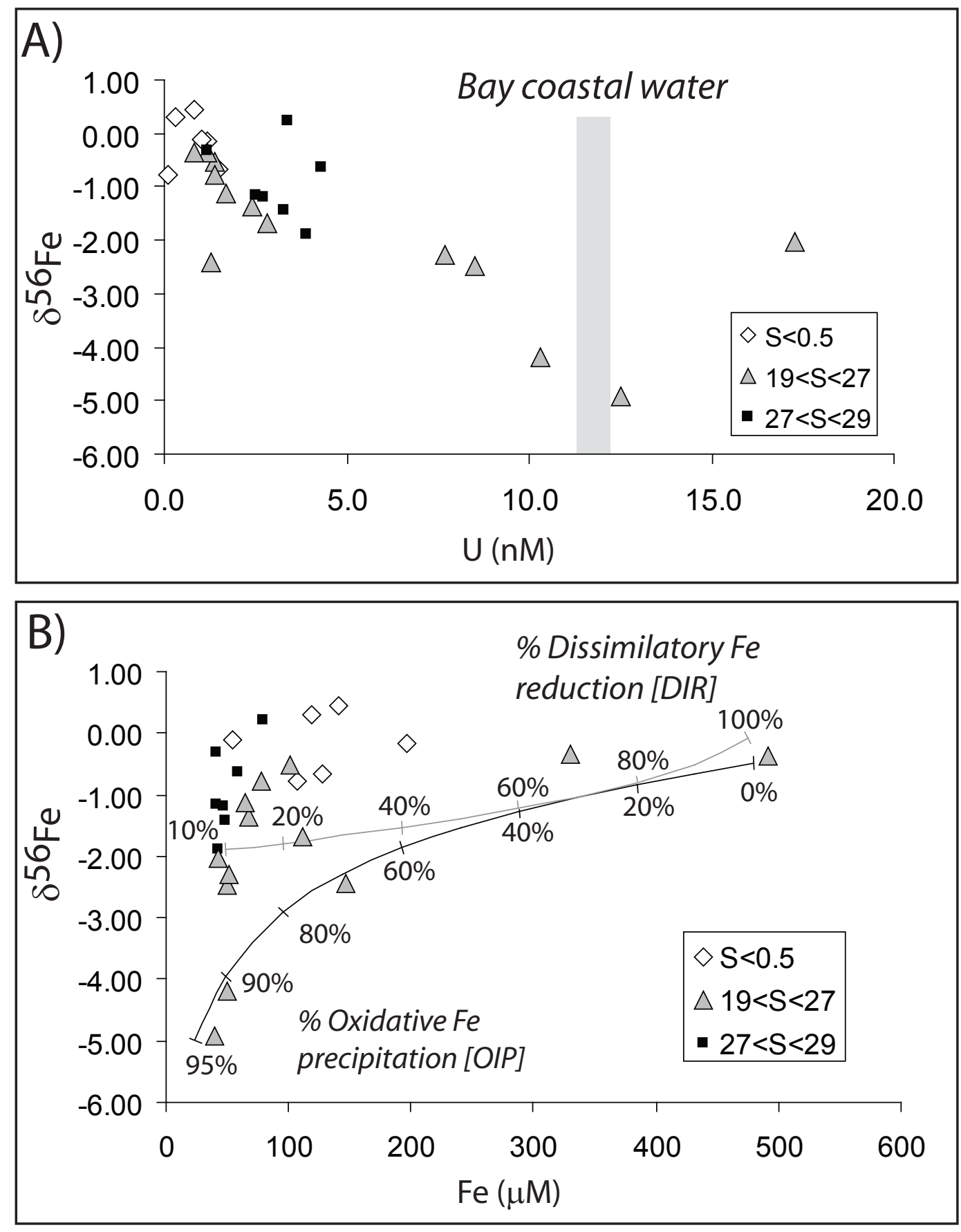

Figure 7 


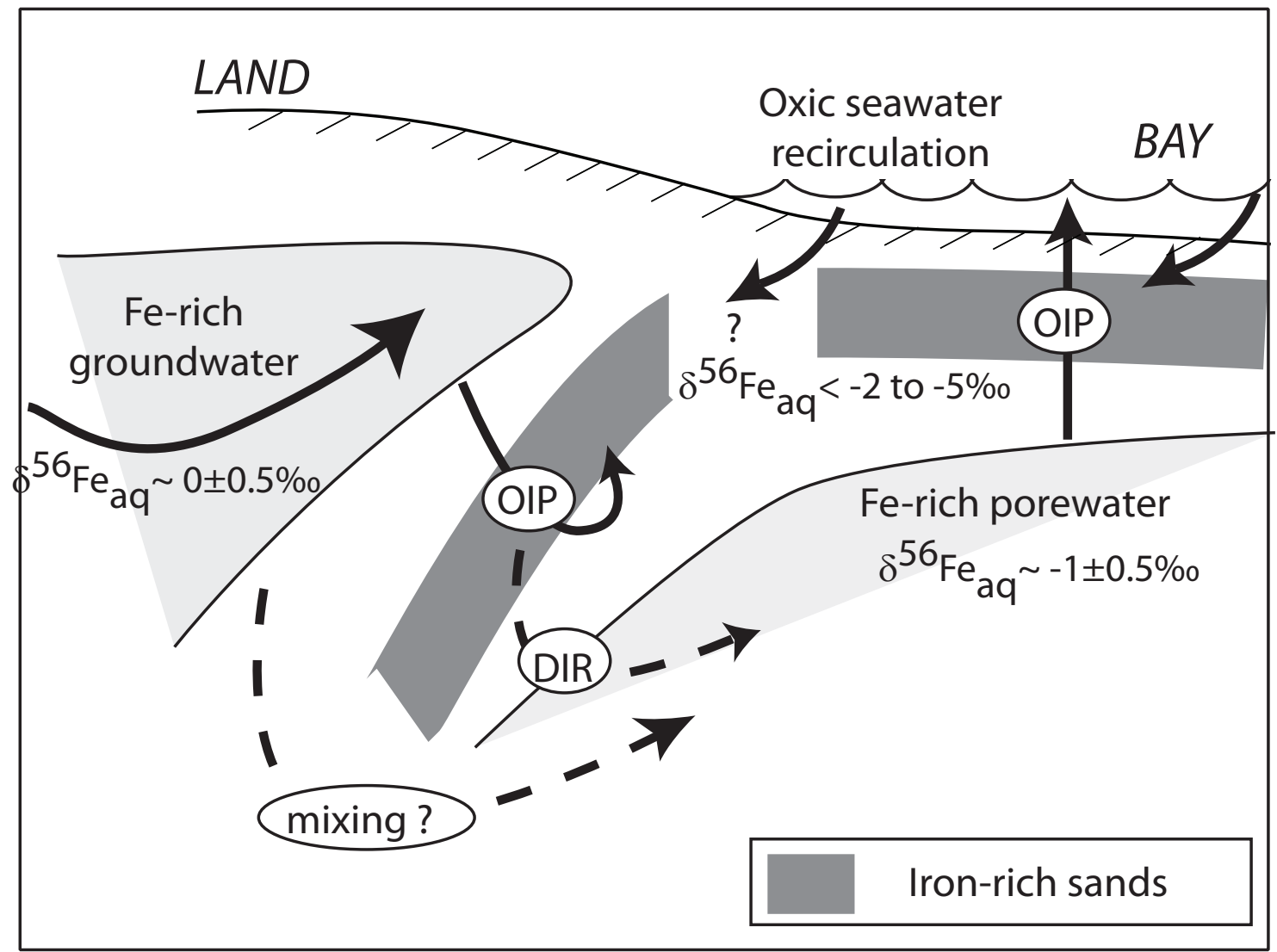

Figure 8 
Table 1. Fe-isotope composition of seawater matrix doped with various amount of Fe isotopic standards (IRMM-14 and BHVO-1)

\begin{tabular}{|c|c|c|c|c|c|c|}
\hline Sample & $\begin{array}{l}\mathrm{Fe} \\
\mu \mathrm{M}\end{array}$ & $\mathrm{N} \#$ & $\delta^{56} \mathrm{Fe}$ & 2SD & $\delta^{57} \mathrm{Fe}$ & 2SD \\
\hline \multicolumn{7}{|c|}{ Seawater* doped with IRMM-14 } \\
\hline \#1 & 5 & 4 & 0.03 & 0.19 & 0.06 & 0.27 \\
\hline \#2 & 5 & 2 & 0.08 & 0.17 & 0.12 & 0.21 \\
\hline \#3 & 10 & 2 & -0.01 & 0.15 & -0.05 & 0.21 \\
\hline$\# 4$ & 10 & 2 & 0.05 & 0.02 & 0.11 & 0.01 \\
\hline Average & & & 0.04 & 0.08 & 0.06 & 0.16 \\
\hline \multicolumn{7}{|c|}{ Seawater* doped with BHVO-1 } \\
\hline$\# 1$ & 10 & 2 & 0.16 & 0.20 & 0.20 & 0.20 \\
\hline$\# 2$ & 20 & 2 & 0.04 & 0.05 & 0.05 & 0.12 \\
\hline \#3 & 50 & 2 & 0.09 & 0.03 & 0.28 & 0.10 \\
\hline$\# 4$ & 200 & 2 & 0.06 & 0.09 & 0.16 & 0.17 \\
\hline \#5 & 400 & 2 & 0.16 & 0.02 & 0.21 & 0.04 \\
\hline \#6 & 600 & 2 & 0.07 & 0.15 & 0.10 & 0.21 \\
\hline Average & & & 0.10 & 0.10 & 0.17 & 0.16 \\
\hline
\end{tabular}

* used $15 \mathrm{~mL}$ of seawater and processed through complete chemical purification procedure. Procedural blank (seawater only) determined at $\sim 0.1 \mu \mathrm{M}$

\# Number of duplicated analysis used to calculate average Fe-isotope isotope composition and precision (2SD: 2 standard deviation) 
Table 2. Pore water concentrations of trace metals, Fe isotope composition of metals and ancilllary water quality parameters

\begin{tabular}{|c|c|c|c|c|c|c|c|c|c|c|c|}
\hline Depth (m) & Salinity & $\mathrm{PO}_{4}(\mu \mathrm{M})$ & $\begin{array}{l}\mathrm{SiO}_{4} \\
(\mu \mathrm{M})\end{array}$ & $\mathrm{Mn}(\mu \mathrm{M})$ & $U(n M)$ & $\mathrm{Fe}(\mu \mathrm{M})$ & $\mathrm{N} \#$ & $\delta^{56} \mathrm{Fe}$ & 2SD & $\delta^{57} \mathrm{Fe}$ & $2 S D$ \\
\hline \multicolumn{12}{|c|}{ Piezometer \#3 } \\
\hline 4.42 & 25.9 & 4.6 & 222.0 & 22.8 & 12.5 & 39.7 & 4 & -4.91 & 0.14 & -7.38 & 0.19 \\
\hline 4.57 & 26.1 & 6.9 & 214.0 & 21.4 & 10.30 & 50.6 & 2 & -4.19 & 0.13 & -6.28 & 0.18 \\
\hline 5.03 & 26.4 & 13.1 & 190.0 & 8.4 & 8.5 & 50.6 & 4 & -2.47 & 0.19 & -3.63 & 0.15 \\
\hline 5.49 & 26.6 & 15.8 & 161.0 & 4.2 & 7.70 & 51.0 & 2 & -2.29 & 0.14 & -3.32 & 0.20 \\
\hline \multicolumn{12}{|c|}{ Piezometer \#4 } \\
\hline 3.96 & 19.1 & 0.9 & 245.0 & 26.1 & 1.3 & 146.0 & 2 & -2.43 & 0.03 & -3.75 & 0.03 \\
\hline 4.42 & 23.2 & 0.5 & 203.0 & 30.0 & 2.8 & 112.0 & 2 & -1.68 & 0.18 & -2.50 & 0.25 \\
\hline 4.88 & 24.5 & 0.7 & 196.0 & 19.6 & 2.4 & 67.4 & 2 & -1.36 & 0.19 & -1.97 & 0.19 \\
\hline 5.79 & 26.5 & 7.8 & 200.0 & 19.4 & 1.7 & 64.5 & 2 & -1.13 & 0.16 & -1.67 & 0.25 \\
\hline 6.71 & 25.7 & 14.1 & 171.0 & 16.2 & 1.4 & 77.6 & 2 & -0.79 & 0.08 & -1.19 & 0.11 \\
\hline 7.16 & 25.7 & 14.2 & 174.0 & 21.3 & 1.4 & 100.9 & 2 & -0.53 & 0.18 & -0.75 & 0.16 \\
\hline 7.62 & 26.2 & 9.6 & 152.0 & 17.4 & 1.2 & 330.0 & 2 & -0.36 & 0.10 & -0.51 & 0.17 \\
\hline 7.92 & 26.5 & 8.9 & 158.0 & 18.9 & 1 & 491.5 & 2 & -0.37 & 0.18 & -0.63 & 0.25 \\
\hline \multicolumn{12}{|c|}{ Piezometer \#5 } \\
\hline 0.15 & 28.8 & 9.4 & 83.4 & 14.1 & 4.3 & 58.9 & 2 & -0.64 & 0.03 & -0.93 & 0.03 \\
\hline 0.61 & 28.8 & 9.4 & 121.0 & 23.6 & 3.3 & 48.4 & 2 & -1.43 & 0.21 & -2.18 & 0.30 \\
\hline 5.18 & 27.5 & 13.1 & 141.0 & 2.6 & 3.9 & 42.6 & 2 & -1.89 & 0.17 & -2.80 & 0.16 \\
\hline 5.64 & 28.1 & 10.3 & 138.0 & 2.8 & 2.7 & 46.7 & 2 & -1.20 & 0.15 & -1.79 & 0.19 \\
\hline 6.55 & 28.9 & 14.3 & 102.0 & 1.4 & 2.5 & 41.5 & 2 & -1.15 & 0.13 & -1.82 & 0.16 \\
\hline \multicolumn{12}{|c|}{ Piezometer \#6 } \\
\hline 1.52 & 0.4 & 0.5 & 27.4 & 5.0 & 0.8 & 141.1 & 2 & 0.44 & 0.03 & 0.74 & 0.05 \\
\hline 1.98 & 0.1 & 2.5 & 16.9 & 1.2 & 1.0 & 54.2 & 2 & -0.10 & 0.12 & -0.21 & 0.14 \\
\hline 7.01 & 25.7 & 1.8 & 202.0 & 29.1 & 17.3 & 42.9 & 2 & -2.03 & 0.13 & -3.07 & 0.16 \\
\hline \multicolumn{12}{|c|}{ Piezometer \#7 } \\
\hline 3.20 & 0.0 & 0.7 & 117.0 & 2.7 & 1.2 & 196.3 & 2 & -0.17 & 0.15 & -0.26 & 0.19 \\
\hline 3.66 & 0.0 & 0.1 & 109.0 & 12.9 & 0.1 & 106.5 & 4 & -0.79 & 0.05 & -1.14 & 0.05 \\
\hline \multicolumn{12}{|c|}{ Piezometer \#8 } \\
\hline 0.61 & 27.6 & 9.3 & 178.0 & 31.3 & 3.4 & 79.0 & 4 & 0.22 & 0.12 & 0.43 & 0.13 \\
\hline 0.91 & 28.4 & 4.8 & 232.0 & 30.0 & 1.2 & 41.2 & 4 & -0.31 & 0.14 & -0.47 & 0.16 \\
\hline \multicolumn{12}{|c|}{ Piezometer \#10 } \\
\hline 3.05 & 0.0 & 0.2 & 23.5 & 3.0 & 0.3 & 119.4 & 3 & 0.29 & 0.12 & 0.45 & 0.21 \\
\hline 3.96 & 0.0 & 0.1 & 25.1 & 4.7 & 1.5 & 128.3 & 4 & -0.66 & 0.11 & -0.89 & 0.15 \\
\hline
\end{tabular}

$\mathrm{PO}_{4}, \mathrm{SiO}_{4}, \mathrm{Mn}, \mathrm{U}$ and $\mathrm{Fe}$ data determined by high-resolution ICPMS from Charette and Sholkovitz, 2006

\# Number of duplicated analysis used to calculate average Fe-isotope isotope composition and precision (2SD: 2 standard deviation) 
Table 3.Chemical composition and Fe-isotope composition of surface beach sediment and sediment cores

\begin{tabular}{|c|c|c|c|c|c|c|c|c|}
\hline Sample & Depth & $\begin{array}{l}\mathrm{Fe}_{\mathrm{T}} \\
\mathrm{ppm}\end{array}$ & $\begin{array}{l}\mathrm{Mn}_{\mathrm{T}} \\
\mathrm{ppm}\end{array}$ & $\mathrm{N} \#$ & $\delta^{56} \mathrm{Fe}$ & 2SD & $\delta^{57} \mathrm{Fe}$ & 2SD \\
\hline \multicolumn{9}{|c|}{ Surface beach sand from Waquoit Bay near the coring sites } \\
\hline Sand "WB" & 0.1 & 426 & n.d. & 2 & 0.04 & 0.17 & 0.13 & 0.27 \\
\hline duplicate* & & & & 2 & -0.06 & 0.12 & -0.07 & 0.14 \\
\hline duplicate & & & & 2 & -0.03 & 0.10 & 0.00 & 0.15 \\
\hline \multicolumn{9}{|c|}{ Surface beach sand from Vineyard Bay, $10 \mathrm{~km}$ from Waquoit Bay } \\
\hline Sand "PB" & 0.1 & 303 & 1890 & 2 & 0.00 & 0.08 & 0.08 & 0.22 \\
\hline duplicate & & & & 2 & 0.06 & 0.10 & 0.10 & 0.20 \\
\hline duplicate & & & & 2 & 0.02 & 0.17 & 0.11 & 0.21 \\
\hline \multicolumn{9}{|l|}{ Sediment Core 2} \\
\hline Core 2-1 & 2.5 & 785 & 23 & 3 & -0.20 & 0.06 & -0.30 & 0.02 \\
\hline Core 2-5 & 22.5 & 744 & 4 & 3 & 0.01 & 0.19 & 0.04 & 0.22 \\
\hline Core 2-10 & 47.5 & 820 & 4 & 3 & 0.14 & 0.09 & 0.29 & 0.17 \\
\hline Core 2-11 & 52.5 & 1106 & 5 & 2 & 0.09 & 0.04 & 0.16 & 0.04 \\
\hline Core 2-15 & 72.5 & 791 & 3 & 2 & 0.35 & 0.08 & 0.51 & 0.15 \\
\hline Core 2-17 & 82.5 & 772 & 4 & 2 & 0.54 & 0.05 & 0.75 & 0.14 \\
\hline Core 2-18 & 87.5 & 1094 & 5 & 4 & 0.48 & 0.24 & 0.70 & 0.32 \\
\hline Core 2-19 & 92.5 & 1279 & 7 & 2 & 0.48 & 0.07 & 0.67 & 0.17 \\
\hline Core $2-20$ & 97.5 & 1373 & 9 & 6 & 0.52 & 0.21 & 0.78 & 0.34 \\
\hline Core 2-21 & 102.5 & 1666 & & 2 & 0.63 & 0.01 & 0.93 & 0.01 \\
\hline Core 2-22 & 107.5 & 1847 & & 2 & 0.65 & 0.02 & 0.96 & 0.01 \\
\hline Core 2-23 & 112.5 & 2279 & 12 & 3 & 0.98 & 0.06 & 1.42 & 0.14 \\
\hline duplicate & & & & 3 & 1.03 & 0.08 & 1.52 & 0.17 \\
\hline Core 2-25 & 122.5 & 2376 & & 2 & 0.92 & 0.02 & 1.42 & 0.04 \\
\hline Core 2-28 & 132.5 & 3255 & 7 & 2 & 1.48 & 0.10 & 2.35 & 0.20 \\
\hline duplicate & & & & 2 & 1.57 & 0.14 & 2.40 & 0.18 \\
\hline Core 2-30 & 138.5 & 2613 & 5 & 2 & 1.39 & 0.04 & 2.09 & 0.10 \\
\hline Core 2-33 & 148.5 & 2040 & 5 & 2 & 1.22 & 0.02 & 1.75 & 0.04 \\
\hline Core 2-38 & 168.5 & 2480 & 6 & 2 & 1.20 & 0.01 & 1.81 & 0.01 \\
\hline duplicate & & & & 2 & 1.26 & 0.05 & 1.84 & 0.01 \\
\hline Core 2-41 & 173 & 2795 & - & 3 & 0.98 & 0.23 & 1.55 & 0.14 \\
\hline \multicolumn{9}{|l|}{ Sediment Core 3} \\
\hline Core 3-17 & 3.2 & 906 & 9 & 4 & -0.56 & 0.17 & -0.83 & 0.29 \\
\hline Core 3-15 & 16.1 & 532 & 16 & 2 & -0.21 & 0.14 & -0.27 & 0.19 \\
\hline Core 3-14 & 24.2 & 659 & 5 & 2 & -0.74 & 0.06 & -1.06 & 0.03 \\
\hline Core 3-13 & 31.8 & 1684 & & 2 & -1.04 & 0.10 & -1.52 & 0.11 \\
\hline Core 3-11 & 46.1 & 2581 & 11 & 3 & -1.76 & 0.15 & -2.60 & 0.16 \\
\hline Core 3-10 & 53.9 & 3625 & 15 & 3 & -1.61 & 0.03 & -2.34 & 0.06 \\
\hline duplicate & & & & 2 & -1.70 & 0.16 & -2.45 & 0.25 \\
\hline Core 3-8 & 69.0 & 2605 & & 2 & -1.27 & 0.03 & -1.86 & 0.02 \\
\hline Core 3-7 & 75.6 & 4883 & 26 & 2 & -1.49 & 0.00 & -2.18 & 0.05 \\
\hline Core 3-6 & 82.4 & 5181 & 27 & 2 & -0.93 & 0.05 & -1.40 & 0.11 \\
\hline Core 3-5 & 89.3 & 5041 & 23 & 3 & -1.14 & 0.09 & -1.71 & 0.17 \\
\hline Core 3-3 & 101.7 & 7588 & 22 & 3 & -0.58 & 0.17 & -0.85 & 0.24 \\
\hline Core 3-2 & 106.4 & 7190 & 17 & 2 & -0.42 & 0.03 & -0.60 & 0.05 \\
\hline
\end{tabular}

\# Number of duplicated analysis used to calculate average Fe-isotope isotope composition and precision (2SD: 2 standard deviatic Fe and Mn concentration determined by reductive leaching method and ICPMS analysis, after Charette et al., 2006

* duplicate analysis include dissolution, chemical purification and mass spectrometry analysis 